UNIVERSIDADE DE SÃO PAULO

INSTITUTO DE PSICOLOGIA

ELAINE CRISTINA GUATER

ESTUDO DOS TRAÇOS HISTÉRICOS DE PERSONALIDADE EM PACIENTES PORTADORES DE CRISES NÃOEPILÉTICAS PSICOGÊNICAS

São Paulo

2010 


\section{ESTUDO DOS TRAÇOS HISTÉRICOS DE PERSONALIDADE EM PACIENTES PORTADORES DE CRISES NÃO- EPILÉTICAS PSICOGÊNICAS}

Dissertação apresentada ao Instituto de Psicologia da Universidade de São Paulo para obtenção do título de Mestre em Psicologia.

Área de Concentração: Psicologia Clínica Orientador: Prof. Dr. Avelino Luiz Rodrigues

São Paulo 
AUTORIZO A REPRODUÇÃO E DIVULGAÇÃO TOTAL OU PARCIAL DESTE TRABALHO, POR QUALQUER MEIO CONVENCIONAL OU ELETRÔNICO, PARA FINS DE ESTUDO E PESQUISA, DESDE QUE CITADA A FONTE.

Catalogação na publicação

Biblioteca Dante Moreira Leite

Instituto de Psicologia da Universidade de São Paulo

Guater, Elaine Cristina.

Estudo dos traços histéricos de personalidade me pacientes portadores de crises não-epiléticas psicogênicas / Elaine Cristina Guater; orientador Avelino Luiz Rodrigues. -- São Paulo, 2010.

$92 \mathrm{p}$.

Dissertação (Mestrado - Programa de Pós-Graduação em Psicologia. Área de Concentração: Psicologia Clínica) - Instituto de Psicologia da Universidade de São Paulo.

1. Histeria 2. Convulsões dissociativas 3. Crises não-epiléticas psicogênicas 4. Psicanálise I. Título. 


\section{FOLHA DE APROVAÇÃo}

Elaine Cristina Guater

Estudo dos traços histéricos de personalidade em pacientes portadores de crises não-epiléticas psicogênicas

Dissertação apresentada ao Instituto de Psicologia da Universidade de São Paulo para obtenção do título de Mestre em Psicologia.

Área de Concentração: Psicologia Clínica

Orientador: Prof. Dr. Avelino Luiz Rodrigues

Aprovado em: / /

\section{BANCA EXAMINADORA}

Prof. Dr.:

Instituição:

Assinatura:

Prof. Dr.:

Instituição: Assinatura:

Prof. Dr.:

Instituição: Assinatura: 
À minha mãe (i. m.) 


\section{Agradecimentos}

Ao meu orientador Avelino Luiz Rodrigues, por ter me acolhido como sua orientanda na Universidade de São Paulo.

Às professoras Léia Priszkulnik e Rosemeire Aparecida do Nascimento pela disponibilidade em participar do meu exame de qualificação e defesa e pelas contribuições oferecidas.

À Camila Munhoz, pelas nossas conversas que tanto contribuíram para a realização deste trabalho e por sua disponibilidade na leitura de meus textos.

Aos amigos da Universidade que trilharam comigo esta jornada, em especial aos integrantes do grupo Sujeito e Corpo - SUCOR.

À Claudia Chernishev, amiga sempre presente. Obrigada por tornar nossos encontros sempre tão divertidos e especiais.

A Lee Cavie, por sua paciência, por suas palavras de conforto e por todos os chás oferecidos com tanto carinho.

Ao meu pai, por ter me ensinado o valor da educação.

A todos os professores que tive desde o início de minha vida escolar, que nutriram meu desejo de conhecer, e aos que me ensinaram a questionar e duvidar do que eu sei.

Por fim, agradeço à Universidade de São Paulo, instituição que me deu a oportunidade de realizar meu mestrado e por todo suporte oferecido durante o programa. 
A alma respira através do corpo, e o sofrimento, quer comece no corpo ou numa imagem mental, acontece na carne.

(Damásio, 2001, p. 18) 


\section{RESUMO}

GUATER, E. C. (2010). Estudo dos traços histéricos de personalidade em pacientes portadores de crises não-epiléticas psicogênicas. Dissertação de Mestrado, Instituto de Psicologia, Universidade de São Paulo, 2010.

A crise não-epilética psicogênica é definida como uma manifestação corporal semelhante àquela das crises epiléticas, porém sem um correlato neurológico que justifique a sua ocorrência. Sua etiologia é atribuída a fatores psicológicos, entretanto as questões subjetivas que estão na origem dos sintomas são pouco estudadas. Esta pesquisa tem por objetivo investigar os traços histéricos da personalidade em dois pacientes encaminhados para psicoterapia de orientação psicanalítica após receberem esse diagnóstico médico, além de analisar os conteúdos afetivos latentes que se relacionam às manifestações sintomáticas nos casos estudados. O material coletado durante o atendimento prestado a esses pacientes se constituiu como registro e fonte de informação, por meio do qual os elementos relativos à personalidade histérica e mecanismos inconscientes que engendram os sintomas são descritos e estudados. Este trabalho tem por referencial a psicanálise e o estudo dos casos foi realizado considerando seus pressupostos conceituais sobre sintoma, conflito, conversão e histeria. O material obtido durante o curso das sessões evidenciou elementos como erotização do espaço analítico, constante reivindicação para ocupar o lugar de objeto de desejo alheio, além da recusa em abandonar a posição de insatisfação e buscar um estado de contentamento. Também foi observado um investimento em fantasias infantis, nas quais há o desejo inconsciente de união exclusiva com as figuras parentais.

Palavras-chave: Histeria; Convulsões dissociativas; Psicanálise; Crises não-epiléticas psicogênicas. 


\begin{abstract}
GUATER, E. C. (2010). A study of hysterical personality traits in patients with psychogenic nonepileptic seizures. Dissertation of the masters, Institute of Psychology of the University of São Paulo.

A psychogenic nonepileptic seizure is defined as a physical manifestation similar to that of epileptic seizures, but lacking a neurological correlation to justify its occurrence. Its etiology is attributed to psychological factors although subjective questions concerning the origin of symptoms are barely studied. This research aims to investigate hysterical personality traits in two patients forwarded for psychoanalytic psychotherapy after receiving this medical diagnosis, as well as analyze latent affective contents associated with the symptomatic manifestations in these case studies. The material collected during the patient consultation served as a file and source of information through which elements relative to hysterical personality and unconscious mechanisms linked to the symptoms are described and studied. This work has psychoanalysis as a reference and the case studies were carried out considering its conceptual assumptions of symptoms, conflict, conversion and hysteria. The material obtained during the sessions evidenced elements, such as erotization of the analytic space, continuous demands to occupy the place of an object of beauty, as well as refusal to abandon discontentment and search for a contented state. Investment in infantile fantasies with an unconscious desire of exclusive union with parental figures was also observed.
\end{abstract}

KEYwORDS: Hysteria, Dissociative convulsions, Psychoanalysis, Psychogenic nonepileptic seizures. 


\section{SUMÁRIO}

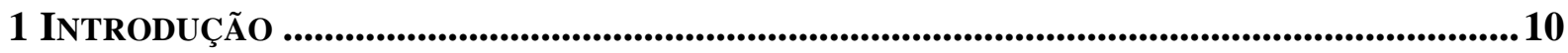

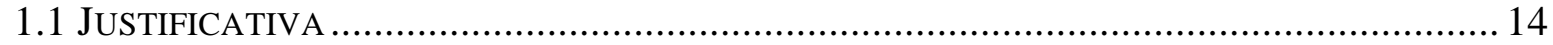

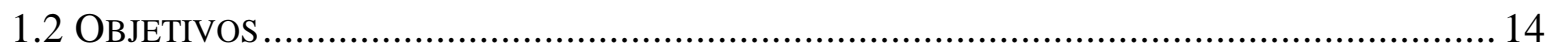

2 Sobre Crises Não-Epiléticas Psicogênicas e a Histeria ...................................16

3 O COMPLEXO de ÉdiPO E SUA RELAÇÃo COM A HISTERIA................................................24

4 Traços da PERSONALIdAde HiSTÉRICA ...............................................................................32

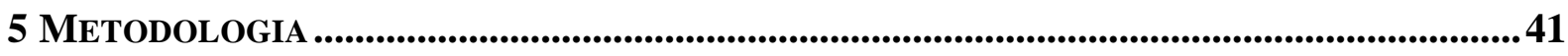

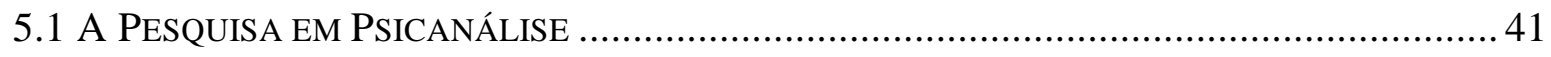

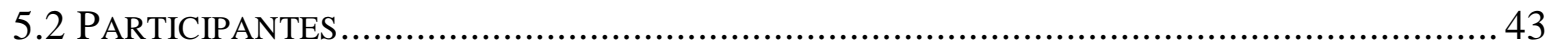

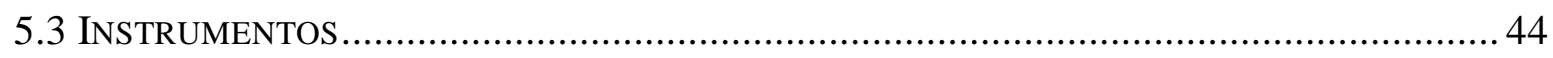

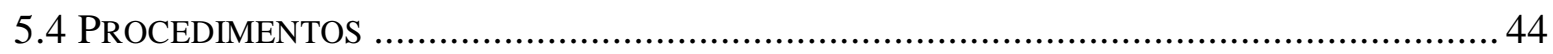

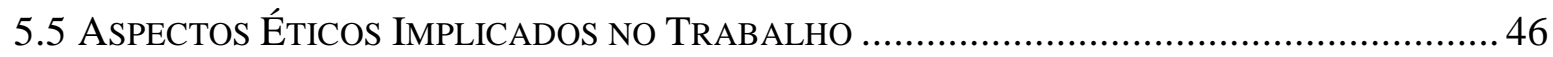

6 Descrição e Análise dos Fragmentos dos Casos Atendidos................................48

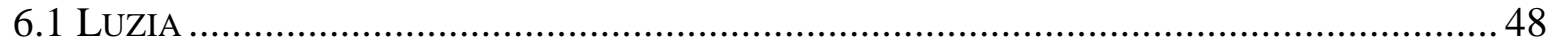

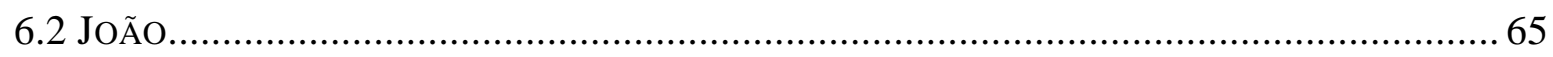

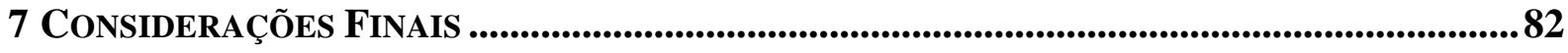

REFERÊNCIAS ........................................................................................................................................86

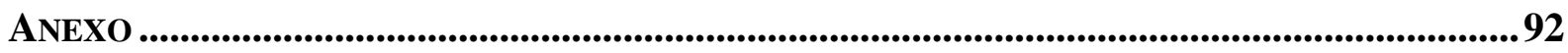




\section{INTRODUÇÃO}

As crises não-epiléticas psicogênicas são manifestações motoras semelhantes àquelas dos ataques epilépticos, mas sem a presença de alterações na atividade elétrica cerebral que justifiquem a sua ocorrência (Aldenkamp \& Mulder, 1997). Os movimentos e sensações dos pacientes podem mimetizar qualquer tipo de crise epilética, e os pacientes que recebem esse diagnóstico podem também apresentar crises epiléticas genuínas associadas. Por se manifestarem de modo semelhante ao que ocorre nas crises da epilepsia, o diagnóstico e tratamento das crises convulsivas sem determinação orgânica constituem um desafio à prática médica atual.

Classificados de acordo com a nosologia médica e psiquiátrica, os portadores de crises não-epilépticas psicogênicas são vistos com considerável frequência em ambulatórios e serviços médicos. Embora o quadro em questão tenha o estatuto de doença para a medicina e, por conseguinte, seja diagnosticado com o rigor e o positivismo que a caracterizam atualmente, a natureza psicológica dos fenômenos convulsivos escapa à racionalidade médica e se situa em uma outra cena, na qual conteúdos emocionais latentes estão atuantes.

O que se supõe determinar as manifestações desses fenômenos são afetos e conflitos emocionais (Aldenkamp \& Mulder, 1997). No campo da medicina existem estudos que relacionam às crises psicogênicas fatores como trauma, abuso e estresse, além de diversos tipos de transtornos de personalidade que podem estar na origem dos sintomas (Taoufik, Alsaadi, \& Marquez, 2005).

A prevalência das crises psicogênicas varia de 5\% a 20\% na população de pacientes com epilepsia. Naqueles com epilepsia refratária, a prevalência é de 20 a 45\% (Fiszman, Alves-Leon, Nunes, D'Andrea, \& Figueira, 2004) e entre 75\% e 85\% dos pacientes são do sexo feminino (Taoufik et al., 2005). Essa condição médica está associada na literatura a uma alta incidência de experiências traumáticas, particularmente abuso físico e sexual (Baillés et al., 2004). Entretanto, autores da área médica pedem reserva na interpretação dessas informações que relacionam as crises não-epiléticas psicogênicas às experiências traumáticas, em especial abuso, uma vez que o problema não consiste apenas na experiência do abuso per se, mas sim em como esse evento é vivenciado e conduzido no passado e no 
presente pelo paciente (Prigatano, Stonnington, \& Fisher, 2002). Também é importante salientar que o relato de abuso sexual na infância também é bastante comum na histeria.

De acordo com Fiszman et al., (2004), há evidências de que experiências traumáticas constituam um potencial risco para o desenvolvimento de crises psicogênicas, porém essa condição não pode ser generalizada para todos os pacientes, pois as crises podem ocorrer em outras condições, como cefaleia, após cirurgia craniana, em pacientes com retardo mental e em pacientes que apresentam asma.

Podem também existir em crianças, mas devem ser distinguidas de outros eventos não-epiléticos que são comuns nessa idade, especialmente naquelas com retardo mental (Engel \& Stern, 2004). Além disso, existe uma associação entre história familiar de epilepsia em pacientes com crises psicogênicas. Em um estudo, comparando um grupo de pacientes com crises psicogênicas e uma amostra geral de pacientes psiquiátricos (exceto os psicóticos), foram encontrados relatos mais frequentes de história familiar de epilepsia no primeiro grupo (Jawad et al., 1995).

Conforme Espírito Santo, Maineri, Portuguez \& Mirna (2004), em sua maioria, essas crises são constituídas por fenômenos conversivos ou envolvem processos dissociativos não-somáticos. Sobre a classificação das crises não-epiléticas psicogênicas Fiszman et al., (2004) afirma que elas são caracterizadas usualmente como formas de convulsões conversivas ou crises dissociativas, definidas conforme o DSM-IV. Essa associação entre mecanismos conversivos e dissociativos e crises não-epiléticas psicogênicas pode sugerir, sob o ponto de vista psicanalítico, a presença de mecanismos histéricos atuantes nesses casos. É nessa perspectiva que este trabalho se insere, pois visa realizar um estudo dos traços de personalidade histéricos em dois pacientes que receberam diagnóstico de crises não-epiléticas psicogênicas; sem contudo pretender generalizar ou atestar a presença dos elementos histéricos na totalidade dos pacientes que recebem o mesmo diagnóstico. Pretende-se oferecer a possibilidade de refletir sobre o fato de que elementos histéricos podem de fato estar presentes em alguns casos na constituição dos sintomas psicogênico, e que, portanto, merecem ser considerados.

Poderíamos supor que, ao psicanalista, a tarefa de tratar esses pacientes seria mais fácil, visto que estamos mais familiarizados com as manifestações inconscientes e dispomos de conceitos e de uma teoria bastante estruturada que nos auxilia no entendimento das relações existentes entre subjetividade e corpo, entre organismo e mente. Mesmo considerando todo o estudo extensivo que tem sido realizado sobre a questão da conversão e 
da dissociação desde os primórdios da psicanálise, a histeria não se deixa compreender plenamente. Há algo da histeria que vai além daquilo que podemos definir, pois é próprio dela não se deixar capturar integralmente, de manter-se como enigma e não cessar de surpreender.

Relatos de manifestações histéricas são encontrados ao longo de toda a história. As primeiras referências a elas foram feitas pelos egípcios, registradas no papiro de Kahun, datado do século XX a.C. Nele, são descritos os estados supostamente histéricos e é atribuída a sua causa ao útero e seus movimentos (Cohen, Ferraz, \& Segre, 2006). Na Idade Média houve uma renúncia à abordagem médica da histeria e o termo praticamente deixou de ser utilizado (Roudinesco \& Plon 1998). Na Europa medieval, há registros de diversas manifestações histéricas, que eram compreendidas como fenômenos religiosos e demoníacos. Uma dessas manifestações, denominada "praga da dança", ocorreu entre os anos de 1374 e 1518, quando centenas de pessoas reunidas no meio dos espaços públicos realizavam juntas um movimento frenético, compulsivo e muitas vezes mortal (Waller, 2008). Também durante esse período há relatos de freiras que agiam de forma como se estivessem possuídas por um demônio. Elas imitavam animais, tinham convulsões, gritavam e afirmavam ter relações carnais com a divindade (Sluhovsky, 2002).

A concepção demoníaca da histeria perdurou por alguns séculos. Embora a opinião médica tentasse resistir à ideia da possessão, foi apenas com Franz Anton Mesmer que ocorreu a passagem para uma concepção científica da histeria. Com Mesmer, a histeria escapou das explicações religiosas e transformou-se em uma doença dos nervos (Roudinesco \& Plon, 1998).

Com Charcot a histeria passou a ser considerada uma doença hereditária e funcional, mas foi Freud quem reintroduziu o papel da sexualidade no desencadeamento da histeria e a partir dela desenvolveu sua teoria.

A maneira de conceber a histeria vai mudando ao longo do tempo não apenas devido ao avanço do conhecimento científico, mas também pelas mudanças culturais que ocorreram na história. Os elementos inconscientes que determinam a histeria são os mesmos, mas seus sintomas guardam a capacidade de se modificarem de acordo com a cultura na qual se inserem e com o discurso que a descreve em um determinado momento histórico. Dessa forma, os sintomas histéricos sofrem constantes atualizações. 
Nossa forma de compreensão da subjetividade é determinada pelas características culturais de um tempo. Hoje, a medicina é a instância à qual nos remetemos para a cura de nossos males, e as explicações de nossas doenças estão agora imbuídas de um conhecimento técnico, muito distante da compreensão medieval das doenças enquanto manifestações demoníacas. Com o inquestionável lugar de saber atribuído à medicina em nossa sociedade, os sintomas histéricos assumem cada vez mais uma roupagem médica, e mimetizam com frequência doenças diversas. Ao mesmo tempo em que lidamos com um fenômeno antigo e estudado extensivamente por Freud e seus seguidores, falamos de sintomas que se modificaram ao longo desses anos, que se inscreveram no âmbito da neurologia e que foram medicalizados.

É nessa dimensão que se situa este trabalho, pretendendo-se considerar os mecanismos inconscientes que engendram os sintomas sem desconsiderar o contexto atual no qual eles estão inseridos.

Sabemos que a divisão entre mente e corpo não existe na realidade, pois nossas bases orgânica e psíquica dão um suporte contínuo e integrado à formação dos sintomas, e se apoiam mutuamente. Portanto, reconhecendo a necessidade de superar essa dicotomia, partimos do pressuposto de que um sintoma é uma expressão marcada pelas relações indissociáveis entre o orgânico e psíquico. Tendo em vista esse pressuposto, neste trabalho o termo 'crises não-epiléticas psicogênicas' foi utilizado com o único intuito de classificar essa condição e marcar a diferença existente entre ela e a epilepsia, sem desconsiderar que elementos orgânicos e psíquicos estão presentes e atuantes mesmo nas manifestações ditas psicogênicas. Não se pretende, na presente pesquisa, se posicionar a favor da primazia da causalidade física ou psíquica das crises não-epilépticas psicogênicas. Freud superou esta dicotomia quando formulou o conceito de pulsão, posicionando-a entre o somático e o psíquico, e a definindo como representante psíquico dos estímulos provenientes do corpo. Assim sendo, para o analista é importante não se prender à questão do determinismo somático ou psíquico e sim considerar um sintoma à luz da história emocional do sujeito. A diferenciação entre um quadro somático e psíquico embora seja de extrema importância para o médico, não se constitui como tarefa do analista, uma vez que cabe a ele tomar o que lhe é dito considerando os sentidos únicos e particulares atribuídos pelo sujeito.

Para Florindo \& Pereira (2003), as crises pseudoepilépticas constituem apenas uma das inúmeras formas de ataque histérico presentes na contemporaneidade, contradizendo a ideia de que os ataques de histeria estariam desaparecendo de nossa sociedade atual. Se 
considerarmos, pela perspectiva psicanalítica, as crises não-epiléticas psicogênicas como sintomas que condensam elementos inconscientes, nosso olhar será lançado para uma problemática desconhecida do próprio sujeito, que tem sua expressão no corpo. Um corpo que, segundo a concepção inaugurada pela psicanálise, é revestido por um caráter simbólico e que não mais pode ser definido apenas como um organismo.

\subsection{JUSTIFICATIVA}

O interesse pela realização desta pesquisa surgiu durante o processo de análise dos pacientes, quando pude notar a presença de traços histéricos marcantes no material das sessões. A partir dessa observação decidi elaborar a presente pesquisa, a fim de estudar de maneira mais detalhada e aprofundada os aspectos estruturais da personalidade dos pacientes, considerando as informações obtidas durante os atendimentos como fonte de registros e referências. Foi o contato com o material obtido no curso das sessões o que me motivou a delinear uma pesquisa clínica que privilegiasse a significação inconsciente desses sintomas, assim como os traços histéricos de personalidade dos participantes.

O fazer clínico do psicanalista é marcado pela investigação constante da história emocional do sujeito. Foi Freud quem afirmou que a psicanálise é, além de um modo de tratamento, uma forma ou modelo de investigação, que pode contribuir para a compreensão de fenômenos que não são completamente explicáveis pela lógica consciente. Ela é de grande importância no entendimento dessas manifestações, que apresentam uma lógica subjetiva inconsciente. Dessa maneira, este trabalho propicia uma interlocução entre os saberes médico e psicanalítico, que são distintos, porém podem contribuir um para o outro.

\subsection{OBJETIVOS}

- Investigar, por meio do discurso dos pacientes, conteúdos afetivos latentes que se relacionam às manifestações psicogênicas, tendo em vista que estas são, 
sob a perspectiva psicanalítica, sintomas que têm sua expressão no corpo, condensando um sentido inconsciente e particular do sujeito.

- Verificar e descrever a presença de traços histéricos da personalidade, considerando o material obtido nas sessões com os pacientes. 


\section{Sobre Crises Não-Epiléticas Psicogênicas e A Histeria}

A crise ou ataque epiléptico é uma manifestação estereotipada, com ou sem alteração da consciência, cujas manifestações podem ser bastante variadas de acordo com a localização das descargas elétricas que ocorrem no cérebro. Os pacientes podem apresentar sinais motores, experiências psíquicas, distúrbios autonômicos e fenômenos neurológicos negativos, tais como perda da voz e tônus muscular. As crises geralmente têm um início súbito e encerram rapidamente de forma espontânea, podendo deixar os pacientes com sonolência e/ou confusão mental (Sander \& Hart, 1999).

Em contrapartida, as crises não-epiléticas psicogênicas são manifestações motoras que se assemelham àquelas dos ataques epiléticos, sem o aumento súbito da atividade elétrica cerebral. Os movimentos e sensações dos pacientes são semelhantes às crises epilépticas, mas não se verifica alterações na atividade cerebral que justifique a ocorrência das convulsões, o que as diferenciam dos ataques epiléticos genuínos. Os fatores psicológicos encontram-se na origem dessas manifestações (Fiszman et al., 2004), e alguns autores entendem tais ataques como sintomas de conflitos emocionais (Aldenkamp \& Mulder, 1997). O termo 'psicogênico' remete à característica que diferencia essas manifestações dos ataques epilépticos genuínos: o componente psíquico que as determina.

Inúmeros termos são encontrados na literatura para nomear esses fenômenos, além de crise psicogênica: pseudocrise, crise histérica, crises funcionais, eventos não-epilépticos, crises psicossomáticas, crises não-epilépticas, entre outros (Prigatano et al., 2002). Segundo Aldekamp \& Mulder (1997), as crises não-epiléticas psicogênicas são frequentemente referidas como "crises histéricas", termo este que pode em um primeiro momento sugerir a consideração da histeria como estrutura de personalidade subjacente nesses indivíduos. Cabe ressaltar, entretanto, que os estudos médicos que utilizam o termo 'histeria' o fazem em geral apenas para diferenciar as crises genuinamente epiléticas daquelas que são ditas psicogênicas. Neles, o termo 'histeria' parece não remeter à personalidade histérica concebida em moldes psicanalíticos, mas sim a uma classe de fenômenos que não constituem epilepsia.

As crises não-epiléticas psicogênicas podem mimetizar qualquer tipo de crise epiléptica podendo ser interpretadas como crises tônico-clônica, ausência e crises 
complexas parciais (Rowan, 2000). Por esse motivo, torna-se pouco provável que um clínico consiga diferenciá-las das epilepsias unicamente através da observação da morfologia das crises. Os pacientes podem apresentar somente episódios convulsivos semelhantes aos da epilepsia, sem apresentar epilepsia associada. Entretanto, muitos pacientes que apresentam crises genuinamente epilépticas também apresentam crises nãoepiléticas psicogênicas.

Algumas pesquisas procuram verificar de que maneira as crises psicogênicas se relacionam a outras condições somáticas que apresentam aspectos psicológicos marcantes. Em seu trabalho, Marquez et al. (2004) evidenciam grande relação entre crises psicogênicas e ganho de peso. Ettinger, Devinsky, Weisbrot, Goyal \& Shashikumar (1999) constatam presença significativa de distúrbios dolorosos nesses indivíduos que tiveram sintomas de dor crônica classificados de moderado a severo, e o grupo dos pacientes com crises psicogênicas persistentes apresentou mais sintomas dolorosos que aqueles que obtiveram remissão das crises. Esses autores sugerem que, em alguns casos, fatores psicológicos talvez contribuam ou sejam as causas predominantes dos sintomas.

Histórias de abuso e trauma são relatadas tanto por pacientes que apresentam transtornos dissociativos como por aqueles que foram diagnosticados como portadores de crises não-epiléticas psicogênicas, o que remete a uma causa psicodinâmica comum; estas últimas podem ser manifestações de um estado dissociativo (Harden, 1997).

As manifestações de caráter psicogênico podem estar presentes em diversas estruturas clínicas (neurose, psicose), em transtornos mentais diversos, bem como em pacientes com estruturas de ego bastante frágeis (Cukiert, 2000; Wolanczyk \& Brynska, 1998). Diversos tipos de desordens da personalidade, mecanismos comportamentais e características situacionais podem resultar em crises não-epilépticas psicogênicas (Aldenkamp \& Mulder, 1997; Prigatano et al., 2002). Sua etiologia é considerada como multifatorial e envolve diferentes psicopatologias e, algumas vezes, disfunção cerebral (Vanderzant, Giordani, Berent, Dreifuss, \& Sackellares, 1986).

Para Espírito Santo et al., (2004), a psicopatologia subjacente em pacientes com crises não epilépticas psicogênicas é bastante variada, porém pouco compreendida. Embora alguns pesquisadores (Baillés et al., 2004; Fiszman et al., 2004) relacionem as convulsões psicogênicas a eventos traumáticos e a outras condições como asma e distúrbios da dor, as questões subjetivas que estão na origem dos sintomas ainda são pouco estudadas. Autores sugerem que os pacientes devem ser avaliados do ponto de vista psicodinâmico, 
independente de apresentarem crises epilépticas genuínas associadas (Espírito Santo et al., 2004).

O diagnóstico geralmente inclui observação de registros de Eletroencefalograma (EEG) ictal e interictal, (durante e entre as ocorrências da crise epiléptica) combinados com consideração de características clínicas subjetivas e objetivas e com o decurso das crises, achados de imagem cerebral, dosagem de prolactina pós-ictal, resposta à medicação anticonvulsivante e procedimentos de indução (Espírito Santo et al., 2004). Para Betts (1999) é possível ter 100\% de certeza que uma crise é epiléptica, mas é raramente possível ter completamente certeza de que não é. Ainda para o mesmo autor as crises não-epiléticas psicogênicas podem ser classificadas em: aparentemente inconscientes, com ou sem movimentos; emocionais; de hiperventilação (respiração acelerada); e desmaios. Quando ocorrem durante a vigília ou sono aparente, o paciente permanece como se estivesse dormindo, mas o EEG mostra atividade elétrica cerebral característica da vigília (Benbadis, Lacman, King, \& Swanson, 1996).

De acordo com Taoufik et al. (2005), exames eletroencefalográficos, presença ou ausência de lesões provocadas pelas crises, a possibilidade de indução das crises por sugestão, testes psicológicos e dados clínicos fornecidos pela história de vida do paciente têm sido insuficientes para a realização do diagnóstico. Por isso, como auxiliar ao diagnóstico diferencial, os neurologistas contam com o uso do Videoeletroencefalograma (VEEG). Nele, as crises, além de serem registradas pelo eletroencefalograma, são filmadas, o que permite uma análise dos movimentos corporais com o correlato neurofisiológico. É um instrumento de grande importância, pois auxilia o clínico na distinção entre as duas classes de manifestações. O diagnóstico de crises psicogênicas é conferido ao paciente quando, no VEEG, as crises convulsivas relatadas e/ou observadas não demonstram alterações cerebrais características (Fiszman et al., 2004). Entretanto, o eletroencefalograma pode mostrar normalidade em pacientes com epilepsia, bem como apresentar alteração em pacientes normais que sofrem de desordens paroxísticas proximais semelhantes às crises psicogênicas, o que dificulta o diagnóstico (Parra, Iriarte, \& Kanner, 1999). Marques, Almeida \& Santos (2004) afirmam que é preciso realizar um diagnóstico preciso entre crises epiléticas e as não-epiléticas, e se referem também sobre a importância de critérios metodológicos para a realização do diagnóstico diferencial.

Um grande obstáculo no tratamento das crises não-epiléticas psicogênicas é a recusa dos pacientes em aceitar o diagnóstico. As razões para esta recusa variam, e alguns 
pacientes referem preocupação com o fato de estarem sendo compreendidos como "loucos", ou ainda julgados como se estivessem mentindo a respeito de suas crises. Para minimizar a rejeição ao diagnóstico autores sugerem a adoção de protocolos sobre como deve ser a comunicação do diagnóstico, porém a questão é complexa uma vez que não há consenso sobre a terminologia que deve ser usada para transmitir a informação ao paciente (LaFrance et. al, 2006).

Existem algumas pesquisas que utilizaram o MMPI (Inventário Multifásico de Personalidade de Minnesota) como um instrumento para identificação dos traços de personalidade mais presentes nos pacientes. Os resultados dos estudos, entretanto, apresentam conclusões diferentes. Em uma pesquisa que utilizou o MMPI, a histeria em sua forma conversiva foi observada como a característica geral do grupo com crises psicogênicas pacientes (Wilkus, Dodrill, \& Thompson, 1984). Outros estudiosos, entretanto, afirmaram não existir um perfil psicológico característico associado aos pacientes portadores de crises não-epiléticas psicogênicas, e que as crises poderiam ocorrer em indivíduos que não apresentam sintomas histéricos e na ausência de uma personalidade histérica clássica (Vanderzant et al., 1986). Tendo em vista a remissão espontânea das crises, pesquisas sugerem que elas podem ainda ser entendidas como reações comportamentais surgidas a partir de circunstâncias externas (Aldenkamp \& Mulder, 1997). Essas diferenças nos resultados dos estudos ocorrem, segundo Vanderzant et al. (1986), devido às características do grupo de sujeitos escolhidos e às diferenças entre as definições utilizadas dos termos 'conversão' e 'histeria'.

O psicanalista sabe que não se deve confundir a presença de sintomas histéricos com uma estrutura de personalidade histérica, uma vez que os sintomas em sua forma isolada não remetem necessariamente à estrutura de personalidade de base. Para Bergeret (1988), um sintoma aparentemente neurótico pode ocorrer em estruturas genuinamente psicóticas, da mesma forma que o oposto também acontece. Seria igualmente mais coerente e preciso falar apenas de sintomas de modo ou linhagem neurótica ou psicótica, para bem assinalar, com isso, do ponto de vista qualitativo, que a natureza do sintoma percebido não explica, de modo algum, um juízo acerca da estruturação profunda do sujeito.

Para Dor (1993), é preciso ater-se ao modo particular e inconsciente da administração dos significantes para evitar o erro de classificar uma estrutura unicamente a partir de suas manifestações sintomáticas. Cada indivíduo tem um modo característico de gestão do desejo, e é a constância dessa gestão que supõe certa estabilidade na organização 
psíquica do sujeito. Há, entretanto, no sujeito histérico uma predisposição ou inclinação favorável aos sintomas de conversão (Dor, 1993). Os mecanismos de conversão e dissociação também são descritos nas crises não-epiléticas psicogênicas, o que sugere uma possível associação entre os dois quadros.

Diversos estudiosos desde os tempos antigos se empenharam em determinar as causas da histeria. Em diferentes momentos históricos os ataques de cunho histérico receberam inúmeras interpretações médicas e religiosas. Interpretações essas que tiveram grande impacto à medida que moldaram a forma com a qual os sintomas eram mimetizados pelos pacientes. De acordo com Trillat (1991), a história da histeria é estreitamente ligada à história da epilepsia, pois tanto uma quanto a outra têm o corpo como alvo. Já na antiguidade é possível verificar o interesse em realizar a diferenciação entre as duas classes de doenças. Hipócrates observou a similaridade entre os ataques epiléticos e as manifestações típicas da histeria, caracterizada como uma patologia causada pela mobilidade do útero, também chamado de matriz, no interior do corpo. Para Trillat (1991), a ideia de que o útero é um organismo vivo que pode ser comparado a um animal, possuidor de certa autonomia e com capacidade de deslocamentos remonta à mais alta antiguidade, cerca de 2000 a.C.

Hipócrates descreveu da seguinte forma o que acreditava ser a etiologia da histeria:

[...] Quando a matriz está no fígado e nos hipocôndrios e produz sufocação, o branco dos olhos revira, a mulher fica fria e mesmo, por vezes, lívida. Ela range os dentes, a saliva aflui à boca e ela se assemelha aos epilépticos. Se a matriz fica muito tempo asfixiada no fígado e nos hipocôndrios, a mulher sucumbe, asfixiada. (Hipócrates citado por Trillat, 1991, p. 19).

Celso, médico latino, também cita a semelhança existente entre epilepsia e histeria, em seu trabalho De re medica (1876), afirma:

Nas mulheres, a matriz é sujeita a doença violenta. Esse órgão é, depois do estômago, o mais propenso a se afetar ou a afetar o corpo. Esse mal tira por vezes a consciência e provoca a queda, como a epilepsia. Ele difere desta por não haver reviravolta dos olhos, nem espuma na boca, nem convulsões, mas somente adormecimento profundo (Celso citado por Trillat, 1991, p. 40). 
Areteu, médico oriundo da Anatólia, aloca a histeria dentro do quadro das doenças agudas. Sobre a sufocação da matriz:

Em geral sempre procura subir para as partes superiores, de modo que a matriz é inteiramente para a mulher como um animal dentro de um animal. Se então acontece repentinamente dela subir para as partes superiores, lá permanecer por algum tempo e comprimir violentamente alguma víscera, a mulher se acha sufocada como num ataque epilético, menos pelas convulsões; pois a compressão subitamente causada pela matriz sobre o fígado, o diafragma, o pulmão e o coração faz com que a paciente pareça sem fôlego e não possa falar. (Areteu citado por Trillat, 1991, p. 26).

Trillat (1991) afirma que foi Soranos quem colocou fim à crença de que o útero seria como um animal. Ele então deixou de ser considerado um corpo estranho, e passou a pertencer à mulher assim como os outros órgãos. No seu Tratado das doenças da mulher, afirma que "essa infecção uterina tem uma grande afinidade com a epilepsia por causa da perda de voz e dos sentidos". (Soranos citado por Trillat, 1991, p. 29).

A ideia do deslocamento do útero é substituída pela teoria da retenção da semente, na qual se acreditava que a mulher teria uma semente análoga ao esperma do homem, e que, se impedida de escoar, causava toda sorte de transtornos e sintomas. A hipótese da sede cerebral da histeria surge pela primeira vez a partir da teoria dos vapores histéricos, formulada por Lange (1689) e Charles Lepois (1563-1633). Lange, em 1689, em seu Tratado dos Vapores, afirma que os fermentos seminais liberam os vapores histéricos, mas que seus efeitos dependem da distribuição destes no organismo. Nas mulheres esses vapores são mais pesados e em situações de abstinência as sementes se acumulam, fermentam, e os vapores liberados desse processo se deslocam para o cérebro (Lepois citado por Trillat, 1991, p. 63). Essas teorias vão sendo abandonadas e, segundo Alonso \& Fuks, (2004), isso ocorre em parte pelo desenvolvimento da neurologia e os avanços científicos, mas primordialmente pelo pensamento puritano que tentava dessexualizar a histeria e retirar da teoria suas explicações tidas como concupisciosas.

Foi Charcot quem realizou um esforço rumo ao diagnóstico diferencial da epilepsia, questão que permanecera aberta desde a antiguidade. Ele propõe o termo histero-epilepsia, no qual a crise histérica e a epilética aparecem de maneira independente e os ataques são distintos. Charcot faz da histeria, assim como da epilepsia, uma doença neurológica funcional (Trillat, 1991). 
Mas é Freud, quem realiza a grande descoberta que modificou a concepção da histeria definitivamente. No seu texto Algumas considerações para um estudo comparativo das paralisias motoras orgânicas e histéricas (1893), ele reconhece que na histeria os pacientes se comportam como se a anatomia não existisse. Freud percebe que as paralisias histéricas se caracterizam por uma delimitação precisa e por uma intensidade excessiva, ao contrário das paralisias ditas cerebrais, sem uma delimitação precisa, havendo em geral um comprometimento concomitante menor. As paralisias cerebrais não conseguem tornar-se absolutas e conservar sua delimitação, pois uma vez que aumentam sua intensidade, elas são acompanhadas por outros distúrbios motores secundários. Contudo, nas paralisias histéricas, mesmo quando eram de grande intensidade, Freud observa que poderia ocorrer um acometimento exclusivo no membro paralisado, sem repercussão para outros membros. Ele então conclui que a paralisia histérica não respeita as regras da localização ou extensão de uma lesão.

Contestando a versão de Charcot, segundo a qual as paralisias histéricas seriam provocadas por uma lesão dinâmica e funcional, Freud observa com precisão que a lesão nas paralisias histéricas é completamente independente da anatomia do sistema nervoso. Conclui que a histeria ignora a distribuição dos nervos e toma os órgãos por seu sentido inconsciente e singular. Freud afirma inicialmente que o que está na base dos sintomas histéricos é uma carga de afeto que se desprendeu de uma impressão psíquica traumática e que o ego se desfaz em reação motora ou atividade psíquica. Nesse momento Freud se aproxima de um conhecimento psicológico novo e com essa descoberta ele inaugura uma nova concepção de corpo, entendido agora como uma estrutura investida de afeto e representações.

De acordo com Mannoni (1989), Freud não põe em dúvida a verdade e a exatidão da neurologia, pois é sobre essa verdade anatômica que irá se fundar a descoberta de Freud a respeito dos sintomas histéricos. O que Freud faz é levantar a hipótese de que existe algo imaginário nas paralisias das histéricas. É ancorado na verdade neurológica que ele tenta refutar as paralisias histéricas. Dessa forma, a psicanálise não foi concebida como uma tentativa de refutar a neurologia, pois ela tomou como seus os pressupostos com base já em sua concepção.

[...] Em presença de uma paralisia, um neurologista deve acabar por achar algo que não funciona em algum lugar na materialidade do sistema dos nervos. Freud, pelo contrário, 
pensa que seria preciso antes olhar para o lado da 'imaginação das histéricas.' Falando assim, não contradiz em nada a ciência dos neurologistas, ao contrário, fundamenta-se justamente nessa ciência para emitir essa hipótese. (Mannoni, 1989, p. 154-155).

A descoberta de que a paralisia histérica estava vinculada a significações desconhecidas dos próprios pacientes tornou possível uma nova compreensão do sintoma neurótico para a psicanálise, que passou a ser estudado à luz dessa nova concepção. $\mathrm{O}$ sintoma se torna um signo que não remete apenas a uma doença com um significado generalizável, mas sim se apresenta como uma formação do inconsciente. O sintoma guarda em si as marcas da vida sexual infantil do sujeito.

Freud em 1900 afirma que o sintoma tem mecanismos análogos ao sonho, pois nele se condensam elementos da vida inconscientes do sujeito. Uma das novidades introduzidas pela nova concepção de corpo elaborada por Freud é a de o sintoma não poder ser definido unicamente como expressão de uma doença, um intruso que deve ser eliminado ou um mal funcionamento que nada tem a ver com a paciente. O sintoma para Freud tem um grande valor, pois ele é como uma mensagem que guarda os sentidos únicos da vida psíquica do sujeito, e dessa forma também a chave para sua superação. Isso não equivale a dizer que a concepção inaugurada por Freud ocupa um lugar privilegiado e único em relação às demais concepções a respeito do corpo. De acordo com David-Ménard (1989), o corpo não é apenas erógeno e não pode ser compreendido apenas por essa perspectiva, senão a psicanálise seria absoluta e teria a última palavra a respeito de tudo. A visão freudiana a respeito de corpo e sintoma não se sobrepõe ou ultrapassa a do corpo doente e sintomático da medicina. Um sujeito considerado doente pela medicina pode ser igualmente tratado pela psicanálise, pois ao analista cabe se ater à questão da estruturação desejante deste paciente que o liga à sua doença e aos demais aspectos de sua vida como um todo. 


\section{O COMPLEXO DE ÉDiPO E SUA RELAÇÃo COM A HISTERIA}

De acordo com Roudinesco \& Plon (1998), em sua obra Freud descreveu duas principais formas de histeria. A primeira denominou histeria de angústia, cujo sintoma central seria a fobia. A segunda, a histeria de conversão, se caracterizaria por representações sexuais recalcadas que tinham sua expressão no corpo. Em 1900, com a Interpretação dos sonhos, Freud faz reflexões sobre os elementos constitutivos dos sintomas histéricos. Ele afirma que as lembranças traumáticas dos histéricos eram de fato fantasias que se manifestavam nos sintomas, assim como nos sonhos. Os sintomas sofreriam a ação de mecanismos análogos ao sonho, como condensação e deslocamento, sendo considerados como uma das formações do inconsciente. Da mesma forma que os sonhos, estes seriam uma tentativa disfarçada para obter satisfação, uma expressão que busca satisfazer as instâncias psíquicas que estão em conflito, entretanto, de maneira paradoxal, causa sofrimento ao sujeito.

Em 1894, no texto As psiconeuroses de defesa, Freud tenta resolver o enigma da passagem do psíquico para o somático, introduzindo o conceito de conversão como o mecanismo que produz, a partir da exclusão de uma ideia inaceitável o redirecionamento do afeto ao nível corporal. O Ego, para defender-se, separaria de uma representação inaceitável, em geral de natureza sexual, o seu afeto correspondente, tornando-a assim inofensiva. $\mathrm{O}$ afeto deslocado da representação seria convertido em sintomas diversos no corpo. Freud já observara, seguindo as pistas deixadas por seus pacientes em suas associações, que os sintomas histéricos tinham em sua origem um evento traumático de natureza sexual. Essa associação entre histeria e conflitos de natureza sexual já tinha sido observada por Charcot e Breuer. No texto A história do movimento psicanalítico de 1914, Freud relata o episódio no qual ouviu os comentários feitos por Charcot e Breuer sobre a importância dos aspectos sexuais no desenvolvimento das neuroses. Esses comentários nunca foram publicamente assumidos, sendo sempre uma questão tratada com discrição. Freud então compreendeu que mesmo no meio médico a "coisa sexual" não podia ser evocada, senão de maneira desviada ou alusiva.

Nos primórdios do desenvolvimento de sua teoria, o relato de suas pacientes levou Freud a acreditar que a causa da histeria seria supostamente a sedução ocorrida por um 
adulto, que teria efeito traumático justamente por ser um incidente sexual primário ocorrido antes da puberdade. Essa experiência traumática seria acompanhada de desgosto e terror. Caso fosse acompanhada de prazer, outro quadro neurótico seria configurado: a neurose obsessiva (Freud,1897/1976). Com essas afirmações, mesmo que preliminares e refutadas posteriormente pelo próprio autor, Freud reintroduz a sexualidade no campo da histeria (Trillat, 1991) e realiza a grande descoberta da sexualidade infantil.

Com o abandono da teoria da sedução, comunicada a Fliess em sua carta de 1897 (a carta 69), o traumático passou a ser considerado não mais como proveniente do exterior, mas a própria sexualidade, no interior do sujeito, passou a ter esse status. A descoberta da dimensão das fantasias sexuais e do desejo vinculado às figuras parentais já configurava o que posteriormente seria considerado no complexo de Édipo como desejos sexuais incestuosos. Miguelez (2007) afirma a esse respeito que, ao reconhecer a existência de um desejo que o sujeito nutre pelas figuras parentais, e não o oposto como se acreditava anteriormente, a teoria da sedução já trazia em si o gérmen do que viria a ser o Complexo de Édipo.

O termo 'Complexo de Édipo' surge na obra de Freud a partir de 1910, em um texto denominado Sobre um tipo de escolha especial do homem, porém nele os desejos incestuosos ainda não foram descritos como tendo um valor central para o desenvolvimento da neurose. Freud afirma que também os desejos homossexuais e orais poderiam estar na base das neuroses, afirmação esta que fica evidenciada na análise do caso Dora, de 1905. Nesse momento de sua teoria, a neurose ocorreria por conta de uma falha no recalcamento de desejos inconscientes infantis diversos. Foi em Totem e Tabu, de 1913, que Freud estabeleceu o vínculo que a criança nutre pelos pais, governado por desejos incestuosos, como o complexo nuclear da neurose. Não apenas da neurose, mas ele aparece como a cena na qual se funda a cultura.

No artigo Uma criança é espancada, de 1919, Freud afirma que a neurose é determinada pelo Complexo de Édipo:

Porque, na nossa opinião, o complexo de Édipo é o verdadeiro núcleo das neuroses e a sexualidade infantil que culmina nesse complexo é que determina realmente as neuroses. O que resta do complexo no inconsciente representa a inclinação para o posterior desenvolvimento de neuroses no adulto (Freud, 1919/1977). 
E não apenas a neurose, mas também as perversões passam a ter sua etiologia relacionada ao Complexo de Édipo. Neste texto de 1919, Freud faz referência ao valor etiológico do Complexo de Édipo, que se estende agora para além da causação das neuroses, e passa a incluir também a perversão. $\mathrm{O}$ autor afirma que "a fantasia de apanhar e outras fixações perversas análogas seriam somente precipitados do Complexo de Édipo, cicatrizes por assim dizer que o processo deixa depois de expirar” (Freud, 1919. p.190).

De acordo com Alonso \& Fuks (2004), o complexo de castração foi adquirindo um caráter estruturante entre os anos de 1909 e 1929. A angústia de castração passa a ocupar o lugar central dentro do Complexo de Édipo. Freud em seu texto de 1926, Inibição, sintoma $e$ angústia, afirma que, ao contrário do que acontece nos homens, a angústia feminina não nasceria de uma falta, real ou imaginária, de um objeto, real ou imaginário, mas da perda do amor por parte do objeto. A menina não sofre a angústia decorrente da ameaça de castração, visto que reconhece a ausência do pênis em si mesma, mas sofre a perda de amor do objeto. Dessa forma, no caso da histeria feminina, a perda do amor corresponderia à ameaça de castração geradora das fobias nos meninos.

Visto não haver qualquer dúvida de que a histeria tem forte afinidade com a feminilidade, da mesma forma que a neurose obsessiva com a masculinidade, afigura-se provável que, como um determinante da ansiedade, a perda do amor desempenha o mesmíssimo papel na histeria que a ameaça da castração nas fobias e o medo do superego na neurose obsessiva (Freud, 1926/1977).

Nesse texto uma diferença é introduzida no caso da mulher: a percepção da perda de amor pelo objeto poderia produzir uma neurose histérica. Ele declara que fixações e recalques poderiam determinar o desenvolvimento das neuroses nesse período, no qual existe um vínculo estreito e particular da menina com sua mãe.

Apesar de Freud caracterizar o Complexo de Édipo como o núcleo da neurose, ele também manifesta interesse pelo estudo dos elementos afetivos que antecedem ao Édipo. Esse período, chamado de fase pré-edípica, é entendido como aquele que precede e possibilita a vivência edipiana, quando se estabelecem as relações de objeto ou do desejo neurótico, a partir da relação entre a mãe e bebê.

Freud irá afirmar em A sexualidade feminina (1931), a esse respeito, que a "fase préedipiana nas mulheres obtém uma importância que até agora não lhe havíamos atribuído". 
No artigo Um caso de paranóia contrário à teoria psicanalítica $a_{2}$ de 1915, Freud desenvolve o tema da vinculação pré-edipiana estabelecida entre a menina e sua mãe. Apresenta o caso de uma jovem que lhe foi encaminhada por um advogado, que suspeitou do caráter patológico da queixa de sua cliente. Após um encontro amoroso, ela passa a acusar de traidor o homem com quem havia tido relações. Acreditava que esse homem havia contratado testemunhas ocultas para registrarem fotos dos momentos íntimos ocorridos entre ambos. Estava convencida de que aquele homem, de posse das fotos comprometedoras, a obrigava a pedir demissão de seu emprego, uma vez que podia constrangê-la divulgando essas imagens. Em seu segundo encontro com Freud, a paciente revela que no dia seguinte ao dia em que julgava que as fotos haviam supostamente sido tiradas, esse homem dirige-se até a empresa onde ela trabalhava e conversa com uma senhora pela qual a paciente nutria afeição. A senhora muito idosa e já com cabelos brancos era considerada pela jovem "como se fosse" uma mãe. A desconfiança da paciente tornou-se absoluta quando viu seu amante e a senhora conversando em particular, e passou a acreditar que o motivo da conversa entre ambos não era nenhum tipo de assunto comercial, mas que conversavam sobre os momentos de intimidade ocorridos entre a jovem e o rapaz. Essa suposta revelação do caso que mantinham teve um grande efeito sobre a paciente e é interpretada por Freud da seguinte forma:

É fácil ver que a idosa chefe de cabelos brancos era uma substituta da mãe, que apesar de sua juventude o amante fora exposto no lugar de pai dela, e que fora a força de seu complexo materno que impelia a paciente a suspeitar de uma relação amorosa entre esses parceiros mal ajustados, por mais improvável que essa relação pudesse ser (Freud, 1915/1977).

O desejo pela mãe fica evidente na afeição nutrida pela senhora, desejos incestuosos que impedia a paciente de seguir o rumo de uma satisfação sexual heterossexual. Freud encontrou nisso a explicação do por que a paciente permaneceu afastada do contato íntimo com homens até a idade dos trinta anos. Ela se protegia de seu amor por um homem por meio de um delírio com características paranoides. A conclusão de Freud a partir da análise empreendida nesse caso é a de que o sintoma é determinado pelas relações infantis íntimas com a imagem materna mais antiga. Nesse texto, o autor não faz referência à histeria, mas sim utiliza esse caso para considerar a possibilidade de que os vínculos muito antigos, 
estabelecidos com a mãe, poderiam estar na raiz de determinados sintomas, nesse caso sintomas paranoicos.

Em A sexualidade Feminina, de 1931, Freud se ocupa em estudar as especificidades da sexualidade feminina. O foco desse artigo é a ligação pré-edípica da menina com sua mãe e as possíveis patologias decorrentes desse vínculo. É precisamente nesse texto que Freud lançará a hipótese de que a histeria, assim como a paranoia, poderia originar-se em um período anterior ao Édipo propriamente dito. Ele afirma que muitos fenômenos da vida sexual feminina que não foram devidamente compreendidos antes podem ser integralmente explicados por referência a essa fase. Ele faz considerações a respeito desse laço libidinal estabelecido nos primórdios da infância do bebê com a mãe, mais especificamente da menina com sua mãe.

Freud está preocupado em responder à questão de como se dá na menina a tarefa de abandonar o que originalmente constituiu sua principal zona genital - o clitóris - em favor de outra nova, a vagina, assim como quando e por que a menina se desliga da mãe numa troca de seu objeto de amor original. Para ele o laço estabelecido entre ambas é marcado por ambivalências e apego e que culmina num desprendimento que decorre da hostilidade desenvolvida pela criança a sua mãe. A hostilidade, de acordo com o texto, é gerada por ciúmes, especialmente se há a presença dos irmãos e pela inveja destes por conta de seus “atributos fálicos". Então, nessa etapa, a relação é marcada pelo forte investimento da criança sobre a mãe ao mesmo tempo em que a hostilidade se faz presente e propicia que a criança se afaste dela, com suas expectativas de amor e desejos frustrados.

O resultado esperado, caso triunfe o recalque, é o afastamento da criança em relação à mãe e a entrada no Édipo propriamente dita, com o abandono da satisfação masturbatória e a ascensão à posição feminina. A menina então se direciona ao pai, não para ter, mas para receber. Decorre desse momento a posição passiva, que para Freud é característica do feminino. Cabe salientar que, segundo o autor, esses investimentos e desinvestimentos da criança, que acontecem nessa fase pré-edípica, só assumem uma significação importante $a$ posteriori, diante do confronto com a diferenciação sexual no Édipo.

Entretanto, o vínculo entre mãe e bebê é tão forte e exclusivo que para Freud existe a possibilidade de um certo número de mulheres permanecer fixado nessa ligação original sem nunca alcançarem uma verdadeira mudança em direção aos homens. Retornando ao texto Um caso de paranóia contrário à teoria psicanalítica, podemos subentender que foi 
isso o que ocorreu com sua paciente, pois seu sintoma expressava sua ligação infantil com a mãe e relutância em abandoná-la como seu único objeto de amor.

A afirmação de que o Complexo de Édipo se constitui como o complexo nuclear das neuroses passa a ser relativizada à medida que Freud faz referência à importância das relações pré-edípicas no desenvolvimento da neurose. O Édipo agora é considerado dentro de uma perspectiva diferenciada, o qual inclui todas as relações da criança com ambos os genitores e passa a ser visto como o resultado final de um processo iniciado bastante precocemente. Para Camargo \& Mello Neto (2006), essa expansão da causação da neurose vai, em anos posteriores, propiciar, em alguns autores, uma certa "dessexualização" da neurose e da psicanálise, sobretudo a partir dos anos 50. Inicia-se uma polêmica entre os que defendem o edipiano e aqueles que defendem o pré-edipiano na constituição das neuroses, entre elas a histeria. Algumas linhas e autores situam a triangulação edípica como o momento central na determinação das diversas estruturas de personalidade, enquanto outros elevam o status do pré-edípico e conferem às primeiras relações estabelecidas entre mãe e bebê importância primordial no desenvolvimento das patologias. Miguelez (2007) afirma, entretanto, que durante o desenvolvimento de sua obra Freud não irá trocar a explicação fálico-edipiana por outra pré-edipiana. Ele propõe, sim, ampliar o Complexo de Édipo e ver nele uma reunião de todas as relações da criança com os seus genitores.

Freud considera duas saídas possíveis para o Complexo de Édipo. A primeira saída, normal ou ideal, resultaria na completa abolição do Édipo, e a patológica com a tentativa frustrada e ineficaz de reprimi-lo (Freud, 1924/1977). Entretanto, vale ressaltar que o próprio autor irá afirmar que a fronteira entre a normalidade e a patologia nunca é nitidamente traçada. Em Algumas conseqüências psíquicas da distinção anatômica entre os sexos (1925/1977), Freud afirma: "em casos normais, ou melhor, em casos ideais, o complexo de Édipo não existe mais, nem mesmo no inconsciente".

Ao se debruçar sobre a questão do fim do Complexo de Édipo, Freud, em seu texto de 1924/1977, afirma que o que ocasiona sua destruição é a experiência de desapontamentos penosos para a criança. A ausência da satisfação esperada levam o pequeno amante a voltar as costas agora já sem esperança ao seu investimento amoroso pelas figuras parentais. Para Freud o Complexo de Édipo se encaminharia para sua destruição por conta dos anseios não correspondidos pela criança, pelos efeitos de sua impossibilidade interna. A outra hipótese que Freud lança mão é a de que o Complexo de Édipo sucumbe justamente porque chegou a hora de sua desintegração, que segue o tempo estabelecido por determinantes hereditários. 
Pode-se, nesse caso, se tratar de um programa inato. O autor afirma que essas duas concepções acerca do que motivaria o fim do Édipo não são excludentes, e, sim, compatíveis.

O menino que se masturba recebe dos adultos ameaças de castração. Ele recusa inicialmente em aceitar essas ameaças, mas ao reconhecer a ausência do pênis nas meninas interpreta-a como tendo sua origem na castração. A angústia decorrida da ameaça de castração leva o menino a se afastar do Complexo de Édipo. As catexias são abandonadas e substituídas por identificações.

Em relação à menina, ao reconhecer em si mesma a falta do pênis sente-se inferior e inveja aquilo que não possui. Freud irá afirmar que a menina aceita a castração como um fato consumado, mas em contrapartida o menino teme a possibilidade dela ocorrer. Para o autor, a menina faz tentativas de compensação, e desliza por meio de uma equação simbólica o pênis para o representante bebê.

Seu complexo de Édipo culmina em um desejo, mantido por muito tempo, de receber do pai um bebê como presente - dar-lhe um filho. Tem-se a impressão de que o complexo de Édipo é então gradativamente abandonado de vez que esse desejo jamais se realiza. (Freud, 1924/1977).

O texto A dissolução do Complexo de Édipo de 1924 tem seu valor por revelar pela primeira vez o complexo de castração como causa geral do abandono do Complexo de Édipo e por afirmar que o destino do Édipo se constitui de maneira diferenciada nos meninos e nas meninas (Miguelez, 2007).

É importante notar que Freud afirma que elementos como bebê e pênis podem ser livremente substituídos no inconsciente um pelo outro. Há como uma equivalência entre o bebê e o falo, e estão no lugar da falta instaurada pela percepção da diferença sexual. A afirmação de que a menina espera ter um filho do pai guarda em si a ideia de que um outro pode oferecer a ela o que ela julga não ter. Lacan, retomando e ampliando essa concepção em sua teoria, fez do falo o significante da falta, a "coisa inatingível”, o próprio significante do desejo, afastando-se assim de uma concepção biológica da sexualidade (Roudinesco \& Plon, 1998). O falo então aparece como um significante que remete à completa satisfação do desejo materno. É sob essa perspectiva que a neurose passa a ser compreendida por Lacan. A dialética do ser e do ter o falo é utilizada como protótipo para compreensão das estruturas 
clínicas. A lógica do desejo na histeria é a lógica da constante reivindicação do falo (Dor, 1993), e isso repercute na maneira como os sujeitos vivem e sofrem.

Estudaremos no próximo capítulo os traços que são frutos dessa dinâmica na qual estão inseridos, entendidos como características que marcam o modo de viver do histérico. 


\section{TraÇOS da Personalidade Histérica}

Quando falamos em traços histéricos da personalidade, nos remetemos às características que fazem parte do modo de existir do histérico. Na literatura psicanalítica existe um abundante número de relatos sobre as características de personalidade mais comuns à histeria, muitos deles com visões distintas ou complementares, o que reflete a multiplicidade dos aspectos presentes nesse quadro.

De maneira geral, pacientes que recebem esse diagnóstico são descritos como sujeitos que apresentam intensos conflitos de ordem sexual, pessoas que recalcam seus desejos e apresentam processos de identificação maciços com o outro. Estão frequentemente se queixando, pois nada lhes parece suficientemente bom, e essas queixas em geral são relacionadas ao próprio corpo, que é sempre um corpo sofredor. Além disso, a realidade dos sujeitos histéricos é preenchida por fantasias das quais são reféns (Bollas, 2000).

Quando pensamos em histeria, pensamos em pessoas perturbadas por suas demandas sexuais corporais e por suas idéias sexuais recalcadas, indiferentes à conversão, superindentificadas com o outro, expressando-se de um modo teatral, preferivelmente devaneando a existência do que propriamente nela se engajando e preferindo a ilusão da inocência infantil a mundanidade do adulto. Sofrem também de sugestão, quer pela fácil influência do outro, quer pela transmissão de suas idéias aos companheiros histéricos (Bollas, 2000, p. 08).

Essas características podem ser encontradas nas demais estruturas de personalidade, porém apenas a personalidade do tipo histérico reúne todos esses elementos em uma forma dinâmica (Bollas, 2000). Além disso, o sujeito histérico tem uma dinâmica inconsciente que lhe é característica. É justamente essa economia desejante do histérico que lhe define, e não seus sintomas, pois eles podem ser encontrados de igual modo em outras organizações estruturais.

Freud, nos Sonhos da bela açougueira (1900/1977), já chamava a atenção para a lógica desejante do histérico, que consistia em manter-se constantemente insatisfeito. É a insatisfação um dos atributos mais evidentes do sujeito que apresenta essa estrutura de personalidade. Há como uma recusa em procurarem um estado de contentamento. A esse respeito, Nasio (1991) afirma que o histérico está constantemente "esperando receber do outro não a satisfação que plenifica, mas curiosamente a resposta que frustra” (p. 14). Essa 
insatisfação, que é uma marca da histeria pode ser compreendida à luz do que ocorre no Complexo de Édipo.

Retomando a concepção lacaniana, é no Édipo que a criança se vê para sempre privada do lugar de objeto exclusivo de amor que completaria o desejo materno. O sujeito histérico investe a si mesmo dessa frustração de amor, e define a si mesmo como um objeto desvalorizado e incompleto. A impossibilidade de ser o falo da mãe, ou seja, de ser aquilo que ela deseja em absoluto, faz o histérico revestir-se de um descontentamento que persiste na queixa arcaica de reivindicação do amor da mãe. O histérico traz em si as marcas dessa interdição instaurada com a entrada de um terceiro, o pai, e sua insatisfação estaria vinculada à percepção de não ter sido amado o bastante por sua mãe, ou de não ter recebido todas as provas desse amor (Dor, 1993).

Palonsky (1997) afirma que permanecer insatisfeito é negar continuamente a castração. Como neurótico que é, o histérico se defende da angústia motivada pela constatação da castração no outro e em si mesmo, e permanece em um círculo de insatisfação cujo objetivo é manter a fantasia de que haverá um Outro-não-falho. Este é um movimento histérico, no qual novos mestres são continuamente eleitos até que se constate que o eleito também está inserido na dimensão da falta.

Já Nasio (1991) refere que a raiz da insatisfação histérica é a ameaça de um prazer tão absoluto que poderia aniquilar o sujeito. Um gozo tão intenso que colocaria a integridade do seu ser em risco. Esse gozo máximo pode ser o gozo do incesto, o sofrimento da morte ou a dor da agonia, pois em sua essência o que ele procura é evitar qualquer experiência que evoque de perto ou de longe um estado de plena satisfação. O medo do histérico é, antes de tudo, o seu medo profundo e decisivo de gozar, nunca sentido, mas atuado em todos os níveis de seu ser. Assim, a estratégia encontrada pelo histérico é permanecer sempre insatisfeito, para que fique protegido da ameaça de um gozo que ele percebe como risco de desintegração e loucura. Para afastar essa ameaça da consciência, o histérico inventa inconscientemente um cenário composto de fantasias destinado a provar a si mesmo e ao mundo que só existe gozo insatisfeito. Por isso, qualquer intercâmbio com o outro conduz inexoravelmente à frustração. Para o autor são o medo e a recusa obstinada de gozar que ocupam o centro da vida psíquica do neurótico histérico.

O 'gozo' é um termo que se tornou conceito na obra de Lacan. Refere-se a uma satisfação que implica a ideia de transgressão da lei, do desafio e da submissão. Lacan o define como um conceito distinto do prazer e o situa na tentativa permanente de ultrapassar 
os limites do princípio do prazer (Roudinesco \& Plon, 1998). O gozo é aquilo que satisfaz, o que o sujeito desfruta, mas que inexoravelmente conduz ao sofrimento e à destruição.

Podemos supor que essa recusa em obter e vivenciar um estado de contentamento e satisfação também se configura como uma solução de compromisso que em alguma medida e de maneira deformada, satisfaz a um desejo inconsciente. A recusa do sujeito em gozar é por si só uma forma de gozo ligado ao prazer autoerótico. A insatisfação seria então a forma encontrada pelo sujeito histérico não apenas de se defender de um gozo absoluto, como afirma Nasio (1991), mas sim de gozar através de um prazer autoerótico no qual o contato genuíno com o outro ficaria para sempre excluído. De fato, isso se evidencia na vida dos histéricos, pois estão sempre distantes de verdadeiros encontros sexuais.

Bollas (2000) inscreve a problemática histérica em uma ambiguidade cujo alvo é o próprio sexo da criança, em uma perspectiva bastante distinta da escola francesa. Segundo o autor, com a intensificação da excitação sexual decorrente da maturação biológica, a criança, apesar de ter tido desde o início de sua existência uma relação erotizada com a mãe, no período edípico passa a considerá-la como objeto de satisfação sexual, e o corpo da mãe, tal qual uma isca, impele a criança para fora do mundo do autoerotismo. O sujeito histérico se ancora justamente nesse ponto, pois se recusa a dar o passo seguinte em direção ao outro. Ele busca um retorno à mãe, idealizando as características não-sexuais dela e assim dessexualiza a si mesmo; ao passo que o sujeito não-histérico avança na sexualização de si mesmo e dos outros. É nesse ponto que se situa o fracasso na passagem edípica (Bollas, 2000).

Para Bollas (2000), a raiz da insatisfação histérica estaria na incapacidade materna de erotizar o genital do bebê. A mãe pode tocar o bebê e transmitir algo desse corpo erótico, mas esse erotismo estará deslocado dos genitais. Assim, o sujeito histérico identifica-se muito cedo com esse ideal materno de ser assexuado e permanece unido a uma mãe pura e casta, em que apenas o prazer do autoerotismo tem lugar. A criança passa a sublinhar na mãe seus aspectos não-sexuais, que se transforma em uma figura imaculada. Sendo assim, a sexualidade genital do histérico fica fadada a sucumbir, diante de um prazer para sempre ligado ao autoerotismo. Ao histérico não é possível responder o que o outro deseja, dado a falta de investimento materno em seu corpo, por isso ele se engendra na busca de evidências do apelo erótico de alguém. Ainda segundo o autor, os constantes pedidos de nossos pacientes para que olhemos e desejemos os seus corpos demonstram a busca incessante por sinais do desejo do outro. Se considerarmos a presença dos sujeitos histéricos nos serviços 
de saúde, demandando cuidados e atenção para seu corpo tido como "doente" e sofredor, podemos entender que se trata de uma tentativa, embora fadada ao fracasso, de capturar através das mãos e do olhar do médico o interesse deste por seu corpo, rejeitado em sua sexualidade pela mãe, em uma época bastante remota.

Mesmo que a mãe não consiga investir as zonas erógenas de seu bebê, é possível que ainda assim ela favoreça o desenvolvimento sexual de seu filho e não o cristalize nessa posição histérica. Nem sempre uma mãe que apresenta conflitos em relação ao sexo do seu bebê produzirá um sujeito histérico. Se a mãe for uma mãe suficientemente boa, como o autor refere, ela, embora ciente de sua "loucura", promoverá uma anti-histeria, desatando os nós que prendem a criança à sua neurose, encorajando a criança a "buscar um objeto mentalmente receptivo às necessidades eróticas" (Bollas, 2000, p. 106).

O conteúdo sexual das fantasias histéricas é de fato um simulacro da sexualidade muito mais próximo dos conteúdos sensuais. É uma evocação longínqua mais próxima das ações masturbatórias infantis do que das fantasias de concretização de uma relação sexual verdadeira (Dor, 1993). Também a esse respeito, Bollas (2000) afirma que muitas vezes os histéricos ficam presos em suas fantasias, em pequenas peças mentais que encenam enquanto fazem amor. Dificilmente são atraídos para fora de si e não se entregam ao prazer de um desejo que se satisfaz com e pelo outro.

Sobre o homem histérico, Dor (1993) afirma que ele nutre a fantasia de ser sedutor o bastante para fazer capturar o olhar de todas as mulheres. Há um desejo narcísico de ser amado, de ser considerado um homem capaz de oferecer à mulher o que ele julga que elas esperam dele. Essa mulher idealizada e inacessível deve sempre permanecer onde está, inacessível, para que o enigma de sua masculinidade seja posto sempre em suspenso, para que nenhuma mulher real ocupe o lugar que outrora foi de sua mãe, e para que ele não se confronte com a realidade do sexo e da castração.

No nível das relações amorosas o histérico do sexo masculino procura seduzir para negociar o amor. Tal como na histeria feminina, esse amor é na realidade um simulacro, já que ele não é capaz de se engajar de fato com alguém, de viver com profundidade um relacionamento amoroso, tornando a sedução um fim em si mesma. O homem histérico também procura "dar a ver" e "dar a ouvir", porém, enquanto a mulher seduz por algo em seu corpo, o homem histérico procura dar a ver com seu corpo inteiro, revelando seu desejo de agradar, de ser reconhecido e considerado valoroso. Dessa inclinação procederia então os comportamentos de ostentação, de parecer ser (Dor, 1993). O homem histérico também 
procura exibir-se para outros homens. Essa característica apenas apresenta uma roupagem homossexual, uma vez que não se trata da real escolha do objeto de amor do mesmo sexo. Essa exibição tem por objetivo afastar a angústia de castração frente à diferença dos sexos. Para o homem histérico, nota-se um maior investimento libidinal vinculado à imagem, muito mais do que ao corpo, como acontece na histeria feminina (Dor, 1993). É nesse ponto de alienação que o histérico pode identificar-se com aquele que possui o falo tanto como aquele que não tem o falo e o reivindica incessantemente. Em ambos os casos é possível constatar essa lógica da alienação subjetiva do histérico, que se esforça por não se deparar com a questão da falta, atribuindo a um outro a possibilidade de ter o falo e o conferir (Dor, 1993).

Na vivência de sua sexualidade, ele sofre frequentemente de impotência (Alonso \& Fuks, 2004; Dor, 1993). Na histeria feminina encontramos a frigidez, enquanto que no homem existe a impotência e a ejaculação precoce como sintomas que remetem à angústia diante da evidência da castração. $O$ ato sexual e, mais especificamente a penetração, é compreendido pelo histérico homem como um chamado para que ofereça o falo à mulher, ou seja, ofereça-lhe aquilo que lhe completará e satisfará de modo absoluto. Como ele não o possui, o sintoma que se origina daí é a impotência, como testemunho daquilo que ele acredita não poder dar à mulher que lhe pede. A impotência manifesta o fracasso em responder ao que o homem histérico acredita ser uma demanda da mulher, impossível de ser satisfeita. É também por meio da impotência que o homem histérico demonstra sua fidelidade à mãe, afirmando que só ela será a depositária de seu desejo. Ao realizar esse pacto inconsciente de fidelidade à mãe, o homem histérico passa a viver a restrição de não gozar com nenhuma outra mulher (Dor, 1993).

A cólera é descrita por autores como Dor (1993) e Alonso \& Fuks (2004) como a principal forma de manifestação da histeria nos homens. A crise de ira para os homens é o correspondente do ataque histérico nas mulheres. As crises de cólera denunciam a impotência do homem diante das dificuldades cotidianas ao mesmo tempo em que têm função catártica, na qual existe uma descarga de energia libidinal.

Segundo Palonsky (1997), é pelo fato de haver no ser humano uma indeterminação na escolha do objeto de satisfação sexual que uma das questões fundamentais da histeria fica posta à mesa. O que o outro deseja e como faço para ser esse objeto de amor absoluto são as perguntas que o histérico procurará responder, tentando apreender o que o outro considera como tendo valor fálico e procurando seguir por essa trilha. O histérico então se 
remete a um outro que pode supostamente responder ao enigma da origem e do processo de seu desejo e o outro facilmente pode tornar-se como um suporte privilegiado dos mecanismos identificatórios.

Longe da verdade sobre sua identidade de ser sexuado, o histérico se identifica com diversos personagens. Para Nasio (1991), o histérico é acometido de grande tristeza que decorre do alto preço de ficar alheio à sua própria identidade. Dessa forma, a tristeza do eu histérico corresponde ao vazio e à incerteza de sua identidade sexuada, buscando no outro/mãe a resposta a esse enigma. Disso decorre os tão conhecidos processos de identificação dos sujeitos histéricos, pois eles estão sempre procurando os objetos do desejo materno, para assim representá-los à mãe. Para Dor (1993), o processo identificatório constitui-se, desse modo, em uma das constantes mais fundamentais do funcionamento histérico (Dor, 1993).

De acordo com Alonso \& Fuks (2004), o sujeito histérico oferece o seu corpo para confirmar o saber médico e se deixa capturar para tornar-se o protagonista da cena. Para os autores, Charcot não escutava o sofrimento das histéricas e sim as deixava fixadas na cena, convidando-as a repetir a fala da louca. As histéricas de Charcot identificadas com o desejo do mestre não negam a se oferecer de modo exibicionista para ajustar-se àquilo que acreditavam ser o desejo do médico. Uma paciente de Charcot, chamada Augustine, fora estuprada pelo amante da mãe aos 13 anos de idade. Alguns dias depois começou a apresentar ataques convulsivos que, a pedido de Charcot, repetia em suas apresentações. Nestas, a paciente reproduzia a cena do estupro, gritando: "Porco! Porco!... Está me machucando! Ele me abria as pernas. Eu não sabia que era um bicho que ia me morder...". Certo dia ela repetiu essa cena 154 vezes. Nesse dia fez acusações a Charcot: "Você disse que me curaria, não era isso?" E cessando o interesse dos médicos por ela, Augustine, que até então alternava seu papel de interna com o de auxiliar de enfermagem, foge do hospital disfarçada de homem.

Vemos nesse relato uma característica marcante da histérica, que é a de permanecer identificada com o que se espera dela, como se seu desejo estivesse alienado ao desejo do outro, de forma que seus sintomas são moldados e atuados de acordo com o que interpreta como sendo o desejo de seu mestre. Pode-se vislumbrar a partir dessas observações que o sintoma histérico está em relação direta com o outro, ele aponta para um corpo que deseja ser visto e seduzir. Portanto, não se pode deixar de considerar que o saber médico tem uma estreita relação na maneira como os sintomas histéricos são configurados. 
Além disso, a histérica apresenta uma particular disposição em identificar-se com um modelo feminino, o que pode ser compreendido como uma tentativa de responder à questão imposta por sua própria feminilidade. E, se a mulher histérica identifica-se com seu modelo, é porque ela acredita que a eleita pode responder à questão crucial da mulher histérica: O que é ser uma mulher? Assim, é possível que uma mulher histérica identifiquese com outra mulher, que se tornará tal qual um modelo, que ela julga ter a resposta para seu enigma. Cabe salientar que esse movimento em busca de um modelo de identificação oculta o passo a dar na aceitação de que na verdade não se tem o falo. Aceitar não tê-lo é potencialmente poder identificar-se com aquela que não tem, mas que o deseja junto àquele que é suposto tê-lo. A identificação histérica pode, todavia, constituir-se pela via daquela que não tem e que, por conseguinte, se dedica a reivindicá-lo (Dor, 1993).

Com o objetivo último de tornar-se mais atraente ao olhar do outro, o histérico procura mascarar suas limitações, contudo a imperfeição nunca se limita apenas ao corpo. Estende-se igualmente à inteligência e ao espírito, de maneira que o "fazer parecer" também está presente nessas dimensões. Por trás da expressão favorita: "eu não sei nada", o histérico traduz seu abatimento de jamais ser o bastante inteligente ou culta ao olhar do outro. Essa queixa permanente encarna-se em inibições sintomáticas, como, por exemplo, os leitmotiv: leio livros, não guardo nada, não compreendo nada de tudo que me ensinam etc... Em resumo, a relação com o saber constitui um terreno eminentemente favorável à atualização dolorosa das imperfeições. O histérico é levado, dessa forma, a se persuadir antecipadamente de que não conseguirá nada dominar do saber por menor que seja. Em tais condições, a solução final é fazer parecer, e tentar ser o reflexo do saber de um outro. Para tanto, ele se torna seu apoio incondicional, numa empreitada de adesão imaginária, e procura tornar-se dele o puro e simples eco, porta-voz de um desejo que vem de um outro, neutralizando suas próprias limitações, fraquezas e lacunas. Um traço histérico marcante é o de estar lá, sem, todavia, estar realmente do lado de seu desejo (Dor, 1993). Tudo pode servir como artifício, com o objetivo último de tornar mais atraente ao olhar do outro aquilo que o histérico presume não ser. A imperfeição nunca se limita apenas ao corpo. Estende-se igualmente à inteligência e ao espírito. De maneira que o "fazer parecer" também está presente nessas dimensões. Como nada nem ninguém é belo o bastante para neutralizar o rastro de suas imperfeições, logo que o menor deslize é percebido, e o ideal mostra-se tão falível como os outros, o histérico pode ser um tirano cruel, apontando e reafirmando ao 
outro o quanto ele é limitado e o quanto suas falhas são insuportáveis e inaceitáveis (Dor, 1993).

Nasio (1991) afirma que o histérico tende à erotização de uma expressão humana, embora ela não seja intimamente de natureza sexual. É o que ele chama de eu histericizante. Sem que ele se dê conta, o histérico sexualiza o que não é sexual, apropria-se através do filtro de suas fantasias de conteúdo sexual - das quais não necessariamente tem consciência. Ainda segundo o autor, ele cria sinais sexuais, porém estes são raramente seguidos pelo ato sexual que podem ser vislumbrados nesses sinais. Para Bollas (2000), o histérico erotiza as situações, tentando aparecer sempre como alguém absolutamente sedutor e sexual, mas esse movimento tem um caráter de satisfação puramente autoerótico. Uma diferença é que para este autor, o histérico investe seu corpo de libido, expressa-se como um ser erótico, com o objetivo de constituir seu corpo como um objeto sexual, já que não conta com as áreas genitais como sintetizadores desse erotismo.

Sexualizar o que não é sexual faz parte do movimento de revelar/esconder que é tão característico dos sujeitos histéricos. Isso também ocorre com a linguagem, uma vez que o corpo sexual do histérico deslocou-se para a linguagem e é através da palavra que ele sentirá sua vida erótica e implicará um outro nessa forma de satisfação sexual. Até mesmo a livreassociação do histérico pode servir a essa função sexual. Na clínica é possível notar a paixão com a qual os histéricos contam suas histórias. Parecem sentir um prazer particular em relatar os episódios de suas vidas, especialmente os dramáticos. $\mathrm{Na}$ análise, eles podem engendrar-se nesse contar e recontar, sem implicar-se de modo genuíno no que dizem. Dessa forma, reproduzem na análise seu modo particular de viver sem realmente implicar-se com a vida (Bollas, 2000).

Ainda segundo o autor, a repetição de suas narrativas tem o objetivo de manter o sujeito na dimensão do imaginário. O histérico conta sua história com um impacto geralmente dramático e pode apresentar um tema ao analista não para que seja apropriadamente examinado e sim para que ele o capture pelo poder da imagem. Se, nesse caso, o analista oferecer uma interpretação que explore o inconsciente, o histérico logo irá rechaçar essa "interferência" para macular a versão primeira e genuína com revisões. A palavra ocupa um espaço central na análise por meio dos relatos, associações e interpretações que nela ocorrem. Assim, o contexto analítico se constitui como um lugar bastante favorável para que ocorra a histericização desse campo (Bollas, 2000). 
Freud afirmou que a histeria se constitui na realidade como uma forma de defesa e uma expressão de um conflito psíquico. Sua especificidade estaria, portanto, na forma particular com que o sujeito se organiza em torno da angústia procedente de suas fantasias sexuais infantis. Os adjetivos histérico, obsessivo e fóbico, dizem respeito às formas distintas de defesa utilizadas pelo eu para se defender de elementos inconscientes de natureza sexual que são geradores de angústia. Tanto o histérico, quanto o fóbico e o obsessivo, se defendem da mesma "coisa sexual", conforme afirma Nasio (1991). 


\section{Metodologia}

\subsection{A Pesquisa em Psicanálise}

Esta pesquisa foi realizada por meio do método psicanalítico, que possui pressupostos que o caracterizam e o distinguem dos demais métodos de investigação do fenômeno subjetivo. Optou-se por esse método porque ele possibilita o estudo dos elementos singulares e únicos dos casos.

O campo de investigação em psicanálise clínica é configurado como um espaço no qual analista e paciente estão juntos na empreitada de encontrar sentidos particulares e significações inconscientes para aquilo que faz o paciente sofrer. A noção de transferência é central nesse contexto. Freud em A dinâmica da transferência (1912/1977) a define como sendo uma expressão de impulsos eróticos ocultos e esquecidos, um fenômeno universal que existe em todas as relações humanas, mas que na análise se constitui como um instrumento que torna atual e passível de serem apreendidos os conflitos e a dinâmica libidinal do sujeito. É um fenômeno onipresente e universal de reedições dos elementos cuja origem remonta a vida erótica infantil. A transferência em psicanálise torna-se instrumento a favor do método, pois esse campo formado por reedições torna presente no espaço analítico as pulsões que antes estavam em oculto, possibilitando ao analista realizar a leitura dos aspectos inconscientes atuantes na vida do sujeito.

Nessa região intermediária entre a realidade psíquica e a vida real que se constitui o setting analítico, a neurose comum, segundo Freud, é substituída por uma neurose de transferência e os sintomas assumem um significado novo e particular. A fala do paciente, endereçada à figura do analista ganha o status de revelação, e é apenas pelo estabelecimento da transferência entre analisando e analista que é possível intervir. O inconsciente se revela nesse espaço transferencial, surpreendendo tanto o paciente quanto o analista. Os sentidos que são produzidos neste campo da análise permite ao sujeito ter um novo posicionamento diante de seu próprio discurso.

É a experiência da transferência que define o campo no qual a psicanálise está centrada, como método terapêutico. Sendo assim, uma pesquisa que se propõe ser 
psicanalítica toma como um de seus pressupostos o estabelecimento desse campo transferencial e aguarda que dele surjam elementos trazidos de forma espontânea pelo sujeito. Para Birman (1994), o psiquismo com que trabalha a psicanálise é o psiquismo de um sujeito concreto que direciona sua fala para um outro e que tem nesse outro seu polo de referência. Esse sujeito falante demanda o reconhecimento por um outro sujeito. Sendo assim, a análise é uma experiência intersubjetiva, na qual dois falantes são lançados no campo da interlocução. É na escuta de um sujeito que fala para um outro, no caso para o analista, que a experiência analítica se constitui. Este é o campo da experiência transferencial.

Turato (2003) afirma que o psicanalista acumula, ao longo das sessões realizadas, um material abundante e profundo de cada paciente de modo que se torna possível apreender amplamente os fenômenos do universo psíquico desses indivíduos. No método psicanalítico o pesquisador/analista pode ter um número de sujeitos participantes bastante reduzido, pois o que está em destaque é a apreensão profunda e abundante do material surgido ao longo das sessões. O autor ainda afirma que o que caracteriza o método psicanalítico é o fato de o psicanalista utilizar somente pacientes em sua pesquisa clínica, uma vez que o material de pesquisa é o material de análise terapêutica. Além disso, os dados colhidos surgem espontaneamente na relação estabelecida por ambos, e não vêm de uma proposta de assunto já predeterminada e apresentada ao paciente. No caso da pesquisa psicanalítica, o contato entre pesquisador pode compreender meses e até anos com o mesmo paciente/sujeito (Turato, 2003).

Para Mezan (1999, citado por Aguiar, 2001), o que caracteriza a investigação psicanalítica é o mergulho na singularidade do sujeito e o estudo dessa singularidade em profundidade:

Toda investigação psicanalítica é de tipo qualitativo, ou seja, trabalha em profundidade com casos específicos. É o mergulho na sua singularidade que permite extrair dele tanto o que lhe pertence com exclusividade quanto o que compartilha com outros do mesmo tipo: por isso o caso ganha um valor que se pode chamar de exemplar. (p. 15).

Ambertín (2006) afirma que, ao utilizarmos o estudo de caso, a análise pode adquirir maior profundidade e precisão, na medida em que se pode identificar um maior número de determinantes relacionados com a psicopatologia considerada. A autora afirma: 
A apresentação do caso clínico - da maneira como Freud apresentava seus casos- propõe-se a cotejar a teoria com a prática clínica para confrontar a consistência e os tropeços dos conceitos fundamentais da psicanálise, assim como os acertos e dificuldades com que se depara o analista em sua prática. Prática que não é qualquer, já que implica uma incidência psicoterapêutica realizada em um campo determinado, a saber, o da situação analítica (Ambertín, 2006, p. 44).

Sabe-se que a pesquisa em psicanálise está diretamente atrelada ao tratamento, pois ela se produz dentro do processo analítico. Freud (1923/1977), em Dois Verbetes de Enciclopédia, definiu a psicanálise como sendo um procedimento para a investigação de processos mentais, uma forma de tratamento dos distúrbios neuróticos, baseada nessa investigação, e uma disciplina ou teoria composta pela coleção de informações psicológicas obtidas ao longo desse percurso. Nessa afirmação está contida a ideia de que o fazer clínico inclui a investigação de maneira concomitante e interdependente. A psicanálise avança na apreensão de novos conhecimentos, repensando a si mesma como ciência e estabelecendo pontes com outras áreas do saber por meio do atendimento clínico. Cada nova fala ou expressão produzida pelo paciente se torna alvo de investigações por parte do analista, com o objetivo de que, a partir do que está sendo enunciado, novos sentidos se produzam no par analítico e novas contribuições teóricas ocorram para o campo da psicanálise.

\subsection{Participantes}

Os participantes desta pesquisa são dois pacientes maiores de 18 anos, um do sexo feminino e um do sexo masculino, ambos com diagnóstico prévio de crises psicogênicas e que foram encaminhados para psicoterapia de orientação psicanalítica por médicos do setor de neurologia do Hospital das Clínicas da Faculdade de Medicina da Universidade de São Paulo. Inicialmente esses pacientes fizeram parte de um protocolo de pesquisa que incluía apenas pacientes com esse diagnóstico e foram atendidos por mim em uma clínica extensa ao Hospital das Clínicas, local para onde eram encaminhados. Segundo informações fornecidas pelos médicos, a paciente do sexo feminino foi diagnosticada como portadora de crises não-epiléticas psicogênicas e o paciente do sexo masculino, além das crises psicogênicas, apresentou registro de crises epiléticas do lobo temporal direito. Eles 
iniciaram os atendimentos em 2006. Após um ano, prazo máximo de permanência no local, os pacientes manifestaram interesse em prosseguir com o tratamento. Foi sugerido então que continuassem a ser atendidos na Clínica do IPUSP. Dessa forma, os critérios de inclusão desses pacientes se constituíram no diagnóstico médico prévio de crises nãoepiléticas psicogênicas e no encaminhamento médico realizado previamente pelos médicos neurologistas do Hospital, onde estavam sendo atendidos na ocasião. Além disso, foram incluídos apenas os dois pacientes que decidiram continuar com seus atendimentos na clínica do Instituto de Psicologia da Universidade de São Paulo, e que aceitaram participar da presente pesquisa. Ambos assinaram o Termo de Consentimento Livre e Esclarecido.

Embora os pacientes escolhidos estivessem em análise durante a realização desta pesquisa, optou-se por incluí-los como sujeitos deste trabalho devido à relevância dos aspectos observados nos atendimentos e que se relacionam aos objetivos deste trabalho. Considerei significativo o material surgido nas sessões, daí a escolha pelos pacientes em questão.

\subsection{INSTRUMENTOS}

Foram instrumentos da presente pesquisa as entrevistas preliminares e sessões de psicoterapia psicanalítica realizadas com os pacientes.

\subsection{Procedimentos}

Nesta pesquisa foi utilizado o método psicanalítico e casos clínicos foram analisados retrospectivamente na discussão deste trabalho. A formulação da presente pesquisa ocorreu após o início do trabalho analítico. Foram realizados recortes no material obtido durante as sessões com o intuito de delimitá-lo ao tema e aos objetivos propostos.

Para a análise dos dados foram investigados, por meio de um contexto transferencial e a partir das informações colhidas, os elementos psicodinâmicos que engendram a crise, 
bem como os traços de personalidade histéricos dos participantes. A decisão de quando encerrar o relato do material em cada caso clínico deu-se por saturação, quando se julgou ter informações suficientes para investigar elementos relativos aos traços de personalidade histéricos e sentidos latentes dos sintomas apresentados, a partir do material obtido nas sessões.

As informações que são utilizadas para o presente estudo foram obtidas tanto no período em que os pacientes estavam sendo atendidos na clínica extensa ao Hospital das Clínicas quanto naquele que se deu posteriormente, quando os pacientes já estavam na clínica psicológica do IPUSP. O material para análise constitui-se do que foi produzido durante os atendimentos, obtido por meio da técnica psicanalítica de associação livre e atenção flutuante.

Os autores escolhidos como interlocutores na discussão deste trabalho fazem parte tanto da linha inglesa quanto da linha francesa. Optei por não circunscrever a questão do entendimento da histeria a apenas uma abordagem dentro da teoria psicanalítica. Penso ser importante e frutífero a percepção do fenômeno subjetivo à luz de linhas de pensamento diversas. Saliento, entretanto, que há diferenças nos pressupostos de cada autor ao descrever a histeria, diferenças estas que marcam a escola de pensamento da qual procedem, o que deve ser levado em conta na leitura de seus comentários neste trabalho.

Assim, a pluralidade no campo psicanalítico, se por um lado aponta problemas, como o risco do ecletismo esterilizante, por outro lado indica novas possibilidades de superação de um dos maiores obstáculos criados no próprio processo de institucionalização da psicanálise: o impedimento da emergência de diferenças em nome da garantia das certezas adquiridas e do conforto rotineiro das formas instituídas. (Kupperman, 1996, p. 208).

Os textos desses autores serviram como base para a discussão e interpretação dos conteúdos que emergiram nos atendimentos, o que nos proporcionou realizar o estudo do material clínico em sua relação com a clínica da histeria. Contudo, procurou-se evidenciar também as especificidades de cada caso, para evitar o erro do reducionismo estrutural. Neste trabalho, o diagnóstico diferencial não será supervalorizado em detrimento das especificidades de cada sujeito, pois a questão da identificação da estrutura não esgota as complexidades da clínica. Cada caso, em sua medida, é único e é tarefa do analista aprender 
as singularidades de cada indivíduo e não apenas limitar-se à classificação estrutural. Nas palavras de Ambertín,

Não desconhecemos que clinos provém de leito e, portanto, há uma vertente que vincula a clínica à medicina. A colocação clínica da medicina alude a uma generalização que se aplica a cada caso singular. Diz-se em medicina "não há doenças, há doentes" e, justamente, o passado médico de Freud se faz sentir no método clínico, mas com uma variante: a teoria psicanalítica conseguiu construir estruturas clínicas a partir do campo próprio da psicanálise. A colocação do sujeito nessas estruturas é o que realça a generalidade, mas atendendo sempre a uma clínica sob transferência que dá preeminência à "associação livre" do analisando e à "atenção flutuante" do analista; aí não é possível não atender à singularidade. É isto o que afasta a psicanálise do campo médico. A clínica psicanalítica é uma "clínica do caso a caso", mas que se sustenta nos pilares paradigmáticos das estruturas clínicas freudianas (Ambertín, 2006, p. 46).

Dessa forma, este trabalho não pretende reduzir a discussão à questão estrutural, uma vez que se pretende realizar um estudo dos casos considerando suas especificidades e a economia neurótica em jogo.

\subsection{ASPECTOS Éticos IMPLICAdOS NO TRABALHO}

Este trabalho surgiu de observações clínicas realizadas no curso de dois atendimentos psicanalíticos. A participação no estudo foi voluntária e condicionada à assinatura do consentimento livre e informado. O Termo de Consentimento Livre e Esclarecido encontra-se em Anexo neste trabalho. A presente pesquisa foi aprovada pelo Comitê de Ética e Pesquisa com Seres Humanos do Instituto de Psicologia da USP, sob o número 2008.047.

Este estudo segue a Resolução no 16/2000 do Código de Ética do Psicólogo, que normatiza a realização de estudos, pesquisas e atividades voltadas à produção de conhecimento e desenvolvimento de tecnologias. Sob essa perspectiva, o estudo salvaguarda o sigilo das informações obtidas, garante o consentimento voluntário dos pacientes sem que sua recusa implique restrições de seu atendimento na clínica psicológica, assegura o 
anonimato dos participantes e assegura o acesso aos resultados da pesquisa após o seu encerramento, sempre que assim desejarem os participantes. 


\section{DeSCRIÇÃo e Análise dos Fragmentos dos Casos ATENDIDOS}

Nas descrições dos casos que são feitas a seguir, com o objetivo de garantir o sigilo, os nomes dos pacientes foram substituídos, assim como as demais informações que poderiam revelar suas identidades.

\subsection{LUZIA}

Luzia tinha 35 anos de idade, casada, com uma filha e do lar. Foi encaminhada para atendimento com o diagnóstico de crises psicogênicas, que foi conferido após avaliação neurológica. O VEEG foi realizado quando a paciente já estava sendo atendida por mim e o período de monitoramento foi de oito semanas, havendo a retirada total da medicação. Durante o exame não foram registrados eventos epiléticos e tampouco não-epiléticos, sendo descartado o diagnóstico de epilepsia, segundo o psiquiatra que lhe atendia na ocasião. Luzia recebia atendimento em dois serviços distintos ao mesmo tempo: psiquiatria e neurologia.

Após receber o pedido de atendimento, realizei alguns contatos telefônicos para solicitar seu comparecimento à clínica. Houve dificuldades iniciais para nos encontrarmos, pois ora a paciente não conseguia combinar uma data para que o marido pudesse acompanhá-la, ora porque precisávamos escolher um dia no qual ela não tivesse consulta médica no hospital. Após algumas tentativas agendamos a entrevista.

Em nosso primeiro encontro ela veio acompanhada do marido e da filha, que a aguardaram na recepção. Na maioria das sessões Luzia vinha acompanhada por alguém de sua família, em geral pelo marido, filha e por vezes de uma sobrinha. Já nas primeiras sessões foi possível perceber a expressão de dor vislumbrada em seu rosto. Suas primeiras palavras remetiam a um sofrimento, bastante presente, mas impossível 
de ser definido ou explicado. A paciente chorava muito e queixava-se de maneira difusa de sua vida como um todo, descrevendo-a como repleta de tristezas.

Luzia se definia como alguém triste e com dificuldades para superar os eventos que ela considerava traumáticos, como a morte de seu pai. Culpava o irmão pela sua morte, pois acreditava que foi uma discussão ocorrida entre ele e o pai que provocou o AVC que o matou. Ao ser convidada a falar sobre essa percepção de que o irmão era responsável, logo respondia que não estava preparada para comentar sobre o assunto e encerrava a conversa.

Tinha dores de cabeça frequentes, as crises não a deixavam mesmo com as altas doses de medicação e não conseguia dormir. Dizia sempre que iria pedir ao seu médico a troca da medicação ou aumento da dose. Queixava-se de que os remédios não faziam efeito. Sentia tristeza, e buscava convencer-me de que o que sentia não era comum, era uma tristeza muito grande, quase que insuportável: "eu não aguento mais" [sic]. Dizia que não suportaria mais frustrações, pois as situações difíceis que havia vivenciado até então já haviam sido o bastante. Essas situações marcantes foram descritas pela paciente no início dos atendimentos como sendo a morte do seu pai, o nascimento da filha e a tentativa de estupro que alegava ter sofrido.

Em relação às crises que apresentava, considerava um absurdo supor que fossem sinal de alguma questão emocional subjacente. Em nenhum momento os sintomas que se apresentavam no corpo de Luzia, incluindo os ataques, se tornaram de fato enigmas que apontavam para além do orgânico. Eles estavam lá e eram relatados a mim sem que houvesse uma implicação da paciente com seu sofrimento. E assim foi nos primeiros meses de atendimento. Luzia revelava e escondia, falava, mas seu relato era mais um conto do que uma tentativa de produção de sentidos. Progressivamente o choro foi dando lugar às queixas corporais e a paciente passou a desenvolver uma atitude bastante agressiva comigo. Percebia que ela desenvolvera uma modalidade de relacionamento que se caracterizava por desconsiderar e até mesmo desmerecer as intervenções propostas por mim. Dizia que ninguém poderia julgar-se capaz de saber sobre sua vida, dizia que ninguém poderia compreender o que ela havia sofrido. Em uma ocasião, precisei desmarcar alguns atendimentos ao que Luzia reagiu de maneira agressiva, reclamando com ironia que para os pacientes não era permitido faltar, mas ao analista sim. Dizia que se ela precisava ligar e justificar suas faltas, então, eu 
também deveria fazer o mesmo. Reclamou do telefone da secretária que segundo ela estava sempre ocupado. Dizia ainda que o atendimento aos pacientes deveria ser prioridade. Digo então que sentia raiva de mim, pois temia estar sendo preterida, deixada de lado. Respondeu dizendo: "Eu não posso esperar nada de você mesmo. Isso eu já sei” [sic].

Foi possível notar que tradicionalmente, no início de cada sessão, Luzia sentava-se e iniciava sua fala dizendo como se sentia mal com dores por todo o corpo, insônia, tristeza, além de suas tradicionais crises. O corpo de Luzia se tornava bem presente em cada sessão e parecia vir primeiro. "Eu não estou nada bem" [sic], repetia no início dos atendimentos, remetendo-se às situações difíceis que havia vivenciado, mas, ao ser convidada a falar sobre elas, Luzia dizia que não queria falar sobre o assunto naquele momento, não conseguia pensar ou ainda não sabia o que dizer. Esse movimento estendeu-se por inúmeras sessões. Ela repetia sempre: "Não sei, não consigo pensar, não quero falar sobre isso agora" [sic]. Havia sofrimento e angústia e se protegia do exercício do pensamento para afastar esses sentimentos.

Decidi então realizar pontuações quando percebia que Luzia tentava desviar um assunto ou desconsiderava uma intervenção. Ao invés de oferecer interpretações prontas procurei construir os sentidos com ela, oferecendo duas situações e pedindo para que nós pensássemos o que havia de comum entre elas, por exemplo. Essa modalidade de intervenção constituiu um meio mais eficaz, uma vez que implicava a paciente na construção sobre o saber de si mesma.

Em seu discurso não havia relação alguma entre suas crises e sua história de vida. Afirmava que as crises ocorriam em momentos em que estava se sentindo bem e que por isso não estariam associadas a nenhum motivo em particular, sendo para ela uma questão unicamente médica. Certa vez, durante uma das entrevistas, disse: “Eles estão com dúvida" [sic], se referindo aos médicos e ao diagnóstico que afirmavam que suas crises tinham motivações psíquicas. "Mas tenho certeza que não é isso. Preciso ser medicada" [sic]. Alegava que o diagnóstico não havia sido feito corretamente, e que apenas os antigos médicos que lhe deram o diagnóstico de epilepsia é que estavam corretos. Ela me diz nessa ocasião, em tom de ameaça, que pediria um relatório ao seu médico no qual exigiria que ele atestasse a natureza psicológica de suas crises, para 
que assim, caso algo de ruim acontecesse a ela durante uma crise, o médico fosse considerado responsável pelo ocorrido.

Já no início dos atendimentos é possível notar que a paciente utiliza seu corpo como meio de comunicação. Ele funciona como mensageiro de suas fantasias, mas, ao mesmo tempo e especialmente no início do trabalho terapêutico, é um corpo que vem tamponar a fala de Luzia a respeito de si mesma. As queixas físicas que ocupavam quase todo espaço das sessões podem ser compreendidas por diversas perspectivas. Uma delas é a de que o relato insistente de seus sintomas estava a serviço da resistência, uma vez que impossibilitava o trabalho associativo e mantinha afastados da consciência os aspectos mais conflitivos e angustiantes de sua personalidade. $\mathrm{O}$ enunciado de que ela não estava bem, repetido incontáveis vezes logo no início de cada atendimento, revelava um sofrimento real expresso em níveis somáticos, mas buscava recobrir o sentido subjacente a esse discurso, que tinha suas raízes em elementos que iam muito além da dor física. Com frequência ela relatava, nos atendimentos iniciais, que não conseguia pensar e que nada sabia sobre as pontuações que eu fazia. Eu percebia que seu discurso não suscitava questões ou reflexões que fossem além do simples relato.

Quando Luzia dizia nada saber a respeito do que estávamos falando, ou ainda, quando me perguntava sobre o significado de um determinado sonho, ela atribuía a mim o lugar daquela que decifraria seu próprio desejo, delegando ao outro a responsabilidade de reconhecê-lo. Porém, não demorava muito para que a paciente questionasse as pontuações e interpretações que eu oferecia e logo as descartasse.

As crises faziam parte de sua vida desde a adolescência, embora outros sintomas sem correlato orgânico, tais como dores fortes de cabeça e desmaios, já existissem desde a infância. Ela parecia se definir pelos sintomas que apresentava e sua maneira de se relacionar com as outras pessoas era mediada por eles. A primeira crise ocorreu por volta dos 16 anos de idade. Não se lembrava ao certo do evento e o que sabe é por conta dos relatos de sua mãe. Luzia estava dormindo quando sua mãe percebeu que a filha não estava bem, ao escutar que ela respirava de maneira diferente e com dificuldades. Foi ver o que estava acontecendo e percebeu que Luzia estava tremendo muito e se movimentando na cama, enquanto os lábios se tornavam brancos. No dia seguinte, sua mãe disse a Luzia para que ela não tomasse banho, pois não tinha 
passado bem à noite e estava preocupada com o fato de algo poder acontecer com ela no banheiro. A mãe de Luzia, entretanto, não lhe forneceu maiores detalhes de modo que a paciente não sabia exatamente o que havia acontecido. Luzia lembra-se que então foi até o banheiro, sentou-se e subitamente perdeu os sentidos. Quando acordou estava no hospital internada já havia alguns dias. Não sabia porque estava lá. Enquanto relatava esse episódio a paciente parecia colorir seu discurso com grande intensidade dramática, repetindo que durante essa internação quase morreu e o quanto a experiência havia sido horrível. De acordo com o relato da paciente, os médicos e também sua mãe não estavam certos do que havia acontecido, mas ela foi medicada e a partir daí passou a considerar-se epilética.

Ao longo dos atendimentos, Luzia parecia procurar contar-me o que havia de pior em sua vida, conferindo tragicidade à sua fala, como se sempre houvesse um sofrimento a mais. Quando ia a uma festa, quando encontrava parentes, vizinhos, tudo era relatado por ela como sendo ruim e até mesmo as situações prazerosas a faziam se sentir mal. Nisso se evidenciava uma marca de Luzia no mundo, que era justamente sua aparente impossibilidade de sentir prazer. Para ser mais precisa, Luzia recusava qualquer outro meio de gozo que não viesse pela via dos seus sintomas. Às vezes podia-se vislumbrar um sorriso, mas ele logo desaparecia e dava lugar a outras queixas. Era como se Luzia não se autorizasse a estar contente.

A insatisfação característica dos histéricos se fazia bastante presente. Como já foi descrito no capítulo cinco, isso é muito característico da histeria. A satisfação possível parecia apenas ocorrer pela via da doença e da relação com sua filha, descrita como sua única alegria.

Após este primeiro episódio que resultou em sua internação, outras crises se sucederam. A paciente dizia ter sido uma criança saudável, nunca tinha tido nenhum problema de saúde, relato este que foi se modificando ao longo das sessões, quando a paciente passou a falar de mal-estares súbitos e duradouros ocorridos durante a infância, que nunca tiveram um diagnóstico médico conclusivo. Apresentava dores de cabeça e permanecia acamada por vários dias, sem que houvesse justificativa orgânica aparente. Conta que aos 12 anos de idade, perdeu subitamente o apetite por uma semana, ficou acamada, e só voltou a andar após sua mãe dar a ela um chá feito com 
ingredientes naturais diversos. A mãe de Luzia sofria com constantes dores de cabeça e a paciente se lembra das faixas usadas pela mãe na cabeça para aliviar essas dores.

Nota-se assim que na fala dessa paciente havia a percepção de que seus sintomas corporais, seus mal-estares eram um mistério que só melhoravam com o cuidado dos médicos e em especial de sua mãe. De fato, segundo Bollas (2000), os histéricos, ainda crianças, frequentemente já evidenciam sua renúncia sexual, podendo recusar as atividades sociais para permanecer sob os cuidados dos pais. Eles podem ainda ficar doentes numa tentativa de requerer da mãe ou de quem a substitua atenção e cuidados.

Luzia dizia que sempre viveu muito bem com os pais e os irmãos. Considerava-se uma criança feliz que gostava de brincar e se definia como sendo "bastante ingênua" [sic]. No relato de Luzia os pais deram às três filhas menores, incluindo a paciente, um tratamento diferenciado dos demais filhos: elas podiam estudar e não era necessário trabalhar na roça como os outros trabalhavam. Ainda segundo a paciente, eles fizeram o possível para prolongar sua infância e revelava orgulhosa que tomou leite na mamadeira e chupou chupeta até os quinze anos de idade, justificando que seu pai queria "curtir a infância das filhas" [sic]. Ela e suas irmãs menores não comiam "comidas normais" [sic], apenas sopa e mingau, pois seu pai queria que ela e suas irmãs menores fossem cuidadas com carinho e amor. "Nós éramos tratadas como bebês. Sempre me preocupei em brincar. Não sabia o que era sexo nem namoro" [sic]. Nesse relato é possível vislumbrar a fantasia de uma infância inocente, livre da dimensão sexual, que é marcada também pelo desejo de um pai que investe a paciente nesse lugar de bebê. A paciente atribui ao pai o desejo de que ela permaneça como seu objeto de afeto dessexualizado e infantil. Esse desejo de permanecer sendo o bebê do papai é percebido pela paciente como o do próprio pai em relação a ela. Dessa forma se evidencia que essa fantasia parece ter a função de se sobrepor à concepção de uma infância embebida de desejo sexual.

Entretanto, Luzia flertava com a sedução. Dizia ter sido uma criança gordinha e atraente aos olhos dos meninos, que estavam sempre olhando para ela e pedindo para serem seus namorados. Sobre a atenção recebida dos meninos dizia não se importar, mesmo parecendo óbvio que se importava de fato. Sobre os meninos por quem ela se interessou na juventude, dizia que gostava especialmente daqueles que lhe 
escreviam cartas e pediam permissão de namoro para seu pai. Entretanto, aqueles que lhe tocavam recebiam seu total repúdio: "nunca gostei disso" [sic]. Quando Luzia presenciava alguma aula sobre orientação sexual, passava mal e pedia para se retirar. Não gostava de ver "aquelas coisas" [sic]. Falava do nojo que sentia diante das cenas vistas nos filmes educativos da escola e do mal-estar sentido diante do que via. Com o andamento das sessões, questões que envolviam a sexualidade passam a ser evocadas de maneira recorrente em seu discurso. Ela lembra o quanto era agradável esse tempo de inocência e complementa que se assemelhava a um paraíso idílico e longínquo. "Soubesse o quão difícil era casar, nunca teria aceitado" [sic]. Dizia que não estava preparada para o casamento e teria preferido ficar com os pais. Também dizia que não estava preparada para engravidar, apesar de repetir muitas vezes que a filha constituía a única felicidade de sua vida.

Uma característica histérica marcante é a tentativa de dessexualizar a si mesmo e ao outro, construindo uma mãe e um pai ideal que negligencia a sexualidade e que deseja que o histérico permaneça como a sua criança para sempre (Bollas, 2000). A fantasia de viver uma infância pura manifesta o desejo de ser o objeto de amor dos pais, além de proteger contra a angústia decorrente da perda do amor parental, o que para Freud corresponderia à angústia de castração nos meninos. A criança histérica procura ser continuamente alvo do amor materno e paterno. Assim, a dessexualização apaga o registro do genital, tornando o corpo lugar de descarga da pulsão libidinal, de caráter autoerótico.

Curiosamente aqui, além da ideia de criança inocente e assexuada, fica evidente o desejo de ser atraente aos olhos dos demais, o que revela a faceta de seu interesse em seduzir. E ela procurava seduzir de várias formas, ora narrando sua história com grande intensidade, preocupando-se mais em contar do que pensar sobre elas, ora solicitando meu olhar sobre suas dores e sobre seu corpo sofredor. Mas é preciso notar que essa nuance erótica está de fato muito distante da sexualidade, que é causa de horror e asco para a paciente e para os sujeitos histéricos. Não podemos esquecer que o conteúdo sexual das fantasias histéricas é de fato um simulacro da sexualidade, uma evocação longínqua mais próxima das ações masturbatórias infantis do que um compromisso de concretização de uma relação sexual verdadeira (Nasio, 1991). 
Em junho de 2006, Luzia foi internada no Instituto de psiquiatria para investigação diagnóstica e realização do exame Vídeo Eletroencefalografia (VEEG). Durante o período em que ela permaneceu no hospital, continuei realizando os atendimentos semanalmente e a visitava em seu leito. Parte do tempo, ela permanecia na sala do Vídeo e parte do tempo na enfermaria. Na internação, a paciente relatava sempre o quanto era bem ou mal cuidada pelos médicos e pelos enfermeiros. Sentia falta da filha, lembrava-se do pai e de sua morte, ao mesmo tempo em que imaginava o quão terrível seria perder sua mãe. Nesses momentos dizia querer voltar para casa. Certo dia, ela me contou que estava na enfermaria e presenciou subitamente uma convulsão de um dos pacientes que estava internado no mesmo quarto que ela. Luzia não queria ver o homem tendo um ataque, mas já era tarde, e seus olhos viram no outro o que muitas vezes ocorria com ela mesma. Após o ocorrido, claramente identificada com o paciente, Luzia sentiu-se mal e apresentou uma crise em seguida. Ela não estava sendo monitorada nesse momento. Disse que a cena havia sido terrível e, quando perguntei o que havia chamado sua atenção no episódio, me contou que o que mais chamou sua atenção foi o olhar das outras pessoas sobre o paciente, no momento em que ele teve o ataque. Luzia foi capturada especialmente pelo olhar das outras pessoas dirigido ao paciente que estava convulsionando. Digo a ela nesse momento que também seu corpo, através das crises, servia para capturar o olhar das pessoas. Então ela disse: "As pessoas tinham que dar mais atenção aos pacientes com esse tipo de problema. Deveriam ter mais cuidado" [sic]. Atenção era justamente o que ela alegava não receber do marido e esse significante vai marcar todo o discurso de Luzia nesse período, especialmente durante a internação, na qual ela se vê confrontada pela atenção/desatenção conferida a ela pela equipe. Atenção também era o que ela esperava de mim, em nossa relação, e que mascarava uma demanda de amor e cuidado. Depois de sua alta ela recebeu a confirmação de que suas crises tinham origem psicológica e não se tratava de epilepsia, embora nenhuma crise tenha sido registrada na ocasião do VEEG. Eu estava presente no momento em que essa informação foi dada pelo médico. A paciente ficou exaltada, não aceitou o diagnóstico e repetia que certamente era epilepsia seu problema. O médico então, sentindo-se desconfortável diante da recusa da paciente, disse que até podia ser epilepsia, mas que não tinha aparecido no exame, e que se fosse era "coisa mínima", e o remédio que ela continuaria tomando iria protegê-la de eventuais ataques genuínos. Assim, após esse 
relato, Luzia se apegou a essa "coisa mínima", ou seja, à possibilidade de que ela tivesse uma doença orgânica que justificasse os ataques. Luzia não tem epilepsia, segundo a informação recebida pelo médico, mas paradoxalmente ela saiu do hospital com a promessa de continuar a tomar uma dose baixa de medicação para crises. Nos mecanismos conversivos, a ação do recalque pode ser vislumbrada quando, diante do argumento médico de que Luzia não tinha epilepsia, ela continua a localizar sua dor em um corpo cindido por sua história emocional. Assim, a recusa de Luzia ao diagnóstico pode ser compreendida no contexto dos ganhos primários e secundários que a doença pode oferecer. O corpo do histérico é um lugar privilegiado para obtenção de uma satisfação autoerótica de caráter repetitivo, além de obviamente causar sofrimento devido às limitações impostas pelos sintomas, portanto não é tarefa fácil prescindir dele. Luzia prende-se ao gozo do sintoma, impedindo assim um redirecionamento da libido.

Era como se a paciente necessitasse de acreditar que de fato se tratava de uma doença genuína, no caso a epilepsia, pois assim ela se esquivava de se haver com o que de pessoal existia em seu sofrimento. Trata-se de uma tentativa para afastar de si a angústia e também de não se responsabilizar por seu próprio sofrimento. Essa posição de objeto só poderia ser sustentada excluindo-se a ideia de crises mobilizadas por elementos psíquicos. O médico que era supostamente aquele que sabia de sua doença não foi aceito em seus argumentos para que a paciente assim pudesse sustentar seu discurso em relação ao seu próprio sofrimento. Em resumo, a paciente, rejeitando nesse momento posicionar-se enquanto sujeito de seus sintomas, preferia imbuir-se da posição de objeto sob o qual o olhar e os cuidados médicos poderiam se focar. Abandonar a ideia da epilepsia custava muito à Luzia, que além de ficar exposta à angústia perderia seu status de doente que mobilizaca o desejo de conhecer e tratar de seus médicos.

No nível dos ganhos primários, em termos quantitativos, ao definir-se como doente fisicamente, ela mantém afastados ainda mais da consciência os aspectos inconscientes que estão na base das manifestações sintomáticas. Quando o médico informa que suas crises têm raízes em outro lugar que não o corpo, a angústia decorrente de elementos inconscientes que permanecem recalcados se torna mais presente e próxima do campo da consciência, contribuindo para que a paciente tente rechaçar essa ideia. Há uma grande tentativa de manter afastados do Ego os conteúdos 
constitutivos dos conflitos psíquicos geradores dos sintomas, mas, como o recalque falhou, é através desses mesmos sintomas que esses elementos se tornam presentes e passíveis de interpretação.

Certa vez, de volta à clínica chegou antes do horário de nossa sessão para justificar o porquê de não poder ficar para o atendimento. Tinha uma unha encravada no pé. Diz que está passando muito mal e que uma infecção estava instalando-se na unha. Conta-me sobre isso com uma intensidade e com um ar de tragédia que parece que estou a ouvir uma paciente contando sobre uma doença muito grave. A paciente justifica sua falta por meio de uma afecção ocorrida em seu corpo.

Ao se aproximar o encerramento das sessões na clínica onde havia sido atendida durante um ano, ela solicita a continuação dos atendimentos na clínica da USP, uma vez que existia essa possibilidade. Disse, pela primeira vez, que tinha crises psicológicas e que estas conviviam com suas crises de epilepsia. Percebo, nesse momento, que Luzia expressa uma mudança significativa em seu posicionamento diante do trabalho analítico. Antes, pedia ao médico que a liberasse dos atendimentos que realizava comigo, agora, solicita que eles continuassem.

Luzia começa a relatar a insatisfação que sente com o marido. Conta que quando estava grávida sua sogra passou alguns dias em sua casa para auxiliá-la nos afazeres domésticos. Luzia sentiu-se extremamente incomodada com a visita, dizendo que a sogra a maltratava em sua própria casa, não sabendo, entretanto, explicitar com precisão em que consistiam esses disparates. Com ar de desdém, relatava apenas que sua sogra cuidava muito bem de seu filho. "Ela fazia até mingauzinho para o meu marido e assim ele me deixou de lado" [sic]. Luzia ficou irritada, pois nem a sogra e nem o marido deram atenção total a ela. Como a excluída, sentiu-se frustrada e repetia frequentemente que por conta disso nunca perdoaria seu marido e tampouco a sogra. Cabe ressaltar que sua frustração não foi mobilizada apenas pela falta do marido que preferia, segundo seu relato, a companhia e os cuidados de sua mãe nesses meses em que a sogra permaneceu na casa. Também me parece que a paciente ficou enfurecida com o fato da sogra não a ter colocado no lugar de sua preferida. Há uma situação de triangulação na qual a paciente tem a percepção de ser menosprezada e excluída por ambos. Essa percepção é importante pois condensa a ideia bem presente nos histéricos de que não foram amados o bastante e reatualiza a dimensão da perda do amor por 
parte do objeto. Nisso se manifesta outro traço marcante da histeria: a recusa em aceitar ter sido privado do amor dos pais. Assim, os sujeitos histéricos podem assumir a posição de quem reivindica esse lugar constantemente (Dor, 1993).

Luzia se queixava de que seu marido não a satisfazia sexualmente. Na verdade, de acordo com o que relatava nas sessões, ele não a satisfazia de forma alguma. Era descrito como desinteressado, não a ajudava, não a levava para passear e não era carinhoso. Falava do marido com irritação, sublinhando suas falhas. Na ocasião Luzia já estava há três meses sem ter relações com o marido. "Depois do que ele fez comigo" [sic]. Fez o quê? Pergunto. "Ele me destratou, ficou do lado da minha sogra, e isso eu não consigo perdoar" [sic]. Com um tom de quem quer encerrar logo a conversa diz que infelizmente não sente mais vontade (de ter relação). Segundo Luzia, ela vive com ele unicamente por causa da filha. Tem medo de que tirem a guarda da menina se o marido alegar que por conta das crises ela não pode cuidar da filha sozinha.

O sujeito histérico pode manter uma relação com um companheiro bastante insatisfatória, pois assim se preserva da angústia decorrente da constatação da perda de amor dos pais e mantém a fantasia de ser seu único objeto de amor. Tal como afirma Dor (1993), o histérico deseja antes de tudo que seu desejo permaneça insatisfeito, permanecendo sempre distante da lógica da castração, de seu encontro com a falta. Luzia dizia nas sessões que não podia ver sangue, pois isso lhe causava mal-estares e desmaios. Pergunto a ela com quantos anos ela menstruou pela primeira vez, e me surpreendo com sua resposta. Foi tardiamente, aproximadamente aos 17 anos de idade e seu fluxo vinha inicialmente apenas de três em três meses. Ela se lembrou de ter falado à sua mãe que achava que tinha se cortado, pois estava saindo sangue dela. Luzia afirma que em sua vida as coisas sempre aconteceram muito tarde. Os amigos diziam que ela tinha ficado mocinha, mas ela repudiava os comentários. Nunca gostou de ouvir isso deles. Diz que sempre se sentiu assim: "por fora pareço uma mulher, mas por dentro pareço que não cresci" [sic]. Lembra-se, em uma ocasião, que ainda adolescente foi visitar uma mulher que acabara de dar à luz. Quando ela viu o bebê sentiu um cheiro ruim exalado dele: uma mistura de cheiro de leite, sangue e muco, como Luzia o definiu. A paciente disse que por pouco não desmaiou em cima da criança e precisou de ajuda para ser amparada. Desde menina a imagem da faca lhe ocupa os pensamentos. A imagem da faca e do corte aparece novamente nas sessões seguintes à lembrança desse fragmento. Lembra-se do parto e 
diz: "eu tomei anestesia e sinto dores dentro de mim. Sinto dores como se fosse um corte" [sic]. Dessa forma é possível identificar significantes que estão interrelacionados: menstruação, sexo, bebê e corte. Descrevera que certa vez, quando se encaminhava ao dentista, foi abordada e violentada por um desconhecido, não havendo penetração, mas a presença da ejaculação em suas pernas provocou sua perplexidade. Esse episódio gerou grande tristeza e Luzia disse não conseguir esquecer. Sentiu-se um verdadeiro objeto, segundo suas próprias palavras, e o asco tomou conta de si. Desse estupro Luzia associa a lembrança de sua primeira relação sexual, ocorrida após um ano de casamento. O marido, em certa ocasião dentro do carro penetrou-a, apesar dos temores e hesitação de Luzia. Ela também nomeia sua primeira relação como estupro.

$\mathrm{Na}$ época em que a paciente produzia essas associações nas sessões, Luzia vai à casa da irmã e, como ela estava trabalhando, decide ocupar seu tempo arrumando e organizando as gavetas dos armários da casa da irmã. Luzia estava menstruada e foi ao banheiro trocar o absorvente. Quando retornou, enquanto organizava as prateleiras, sentiu um calafrio que começava no pescoço, percorria o seio e passava pela vagina. Sentiu um grande fluxo de sangue que não cessava. Tremeu, sentiu-se fraca e tinha a sensação de que seu sangue vazava pela roupa, inundando a calcinha e seu vestido. Lembrou-se de quando tinha 17 anos, quando o fluxo ocorrera como uma hemorragia. A sobrinha lhe preparou um chá e, aos poucos, a paciente começou a sentir-se melhor. Em suas associações sobre esse episódio diz apenas que passou muito mal, mas não entende o porquê.

Luzia começa a contar sobre sonhos nas sessões. Um deles é descrito da seguinte maneira: "Estava em um lugar, como se fosse em um campo de guerra. As pessoas estavam guerreando, e eu andava no meio delas e me sujava com o sangue delas. Havia sangue em mim, na minha roupa, na minha pele. Estava angustiada" [sic]. Faço uma interpretação abrangendo a imagem do sangue, presente na sessão anterior, e Luzia imediatamente começa a contar detalhes sobre sua primeira experiência sexual, assunto já tratado anteriormente. Luzia sentia dores e, mesmo admitindo que o marido a tratava com carinho, não conseguia deixar que o marido a penetrasse. Um dia, enquanto estavam em uma estrada, o marido acariciou Luzia e tentou penetrá-la. Então, ao perceber que ele não estava disposto a parar, começou a pedir para que ele se afastasse, o que não aconteceu. Assim, Luzia perdeu a 
virgindade, sangrando e sentindo-se violada. Acusando o marido de a ter violado: "Ele não me respeitou" [sic].

Sonhou ainda que estava se casando, com um belo vestido branco de noiva. Recorda-se de estar feliz no sonho, dançando, mas o noivo não estava presente. De repente começou a chover e a água foi tanta que ela tentou se esconder. Lembra-se com nitidez do vestido, que era especialmente belo, com detalhes internos muito bemfeitos. Luzia ficou menstruada e tentou esconder-se da chuva, com medo de que pudesse se molhar e mostrar o sangue que manchava seu vestido. As associações que se seguiram a esse sonho remetiam também à experiência da sexualidade vivida como algo extremamente violento e cruel. Ela conta então sobre seu próprio casamento. Descreve a cerimônia como um momento perfeito, no qual utilizou um belo vestido, com muitos convidados. Entretanto, a paciente contava sobre os detalhes de seu casamento excluindo em seu discurso a dimensão que a unia ao seu marido. Ela descreve o momento como uma bela cena, porém nela o noivo está excluído, não chega a ser mencionado, e quando é lembrado pela paciente o é apenas para apontar nele suas falhas. De fato, Luzia afirmava que não se sentia realizada no casamento. Dizia que lhe faltava algo e que não se sentia realizada.

Gostava muito de carinho, porém o sexo não lhe importava. Afirmava que não procurava o marido porque ele não era carinhoso o bastante. Também dizia que há muito já não se importava mais com os desentendimentos que tinha com ele. Em uma sessão lembrou-se de um livro que leu, recebido de uma amiga que, sabendo de seu interesse por livros de romance, lhe presenteou com um exemplar. Conta a história de uma moça muito bonita e sedutora, mãe de alguns filhos que, perdido o "grande amor de sua vida”, continuava a atrair sobre si a atenção dos homens. Se dizia muito interessada em leituras do gênero, pois gostava de contos de amor.

Analisando esses fragmentos é possível compreender que Luzia sonha em retornar ao estágio primeiro infantil, no qual ela imagina permanecer ao lado dos pais em um estado no qual todos são plenamente felizes e se bastam uns aos outros. Ela evita o contato sexual com os homens, pois acredita que dessa forma irá preservar sua alma da imoralidade e da violência do sexo. A noiva pura e vestida de branco que se suja com o sangue é a imagem do desejo diruptivo, o qual a paciente tenta repudiar, mas não consegue se esquivar. O perigo do encontro sexual a colocaria diante da 
questão central da histeria: a tentativa de compreender o mistério de ser mulher. Luzia demonstra ter uma visão romântica do contato entre homem e mulher e julga ser violenta a porção densa, instintiva e agressiva que o sexo encerra. Ela permanece no impasse entre ser a noiva feliz e ingênua do vestido de noiva e a noiva desejante que se suja de sangue. Medo de sangrar e desejo de sangrar andam lado a lado, e sob as vestes brancas que ela usava irrompe o instintual, o incontrolável e o impossível de sua sexualidade.

Nesse fragmento relatado pela paciente pode-se perceber sua impossibilidade de obter prazer sexual genital. Ela se distancia de todo encontro real e nutre fantasias envolvendo um parceiro romântico, carinhoso e puro. Ela dizia sentir asco em relação ao sexo, descrevendo-o como nojento. Freud (1905/1977) define esse elemento como característico dos sujeitos histéricos, afirmando que "tomaria por histérica, sem hesitação, qualquer pessoa em quem uma oportunidade de excitação sexual despertasse sentimentos preponderante ou exclusivamente desprazerosos, fosse ela ou não capaz de produzir sintomas somáticos”. A imagem do sangue e do corte remete à associação que Luzia faz entre o contato íntimo e genital com o outro a algo da ordem do horror e da destruição. A menstruação nesse caso pode ser compreendida também como símbolo que marca o fim da infância, a possibilidade de engravidar e é, portanto, expressão real da sexualidade repudiada e temida pela paciente. Para Freud, a vagina materna é aterrorizante pelo fato de forçar a criança a confrontar sua ansiedade com relação à castração, mas também, para Bollas (2000), anuncia o choque elementar de que a mãe se foi para sempre, significando a morte da infância. Assim, nisso consistiria a associação do orgasmo com a morte, que se torna bem evidente particularmente nos sonhos e nas fantasias diurnas de Luzia. Quando ela se sente mal diante da faca, ou quando sentia mesmo após anos decorridos do parto como que alguém lhe cortando por dentro, ou ainda quando teme as próprias fantasias de suicídio, nota-se que seu prazer está ligado a essa dimensão do traumático, do destrutivo e consequentemente da morte.

Acredito que muito embora Luzia apresente aspectos masoquistas bem marcantes, a violência do ato sexual, sempre presente em seus pensamentos, sonhos e fantasias remetem a vivência de uma satisfação de um desejo que nunca pode ser realizado plenamente, pois ele é imbuído de sofrimento e destruição. Sendo assim, o sofrimento e a dor associados à vida sexual que aparecem em seu discurso podem ser 
compreendidos ao mesmo tempo como satisfação de seus desejos masoquistas e como punição contra os desejos edípicos infantis. Tal com afirma Bollas (2000), a angústia da castração, o medo da mutilação genital não surge só como consequência dos ímpetos incestuosos imaginados, mas como ataque ao seu próprio genital e ao do outro.

O estupro que Luzia diz que sofreu, quando um desconhecido se masturbou e ejaculou em sua roupa, é nomeado pela paciente como um episódio "traumático". Trauma este que parece decorrer da brutalidade com que o desejo sexual se impõe. Ela se viu reduzida a simples objeto de desejo, foi pega de surpresa pelo horror e pela violência do sexo, mas também pela satisfação que o olhar desejante do outro lhe proporcionou. Assim, os momentos mais difíceis que ela julgava ter vivenciado: a morte do seu pai, o nascimento da filha e a tentativa de estupro que alegava ter sofrido são eventos que remetiam todos à questão da castração e à sua feminilidade, e neles foram reeditados seus afetos mais infantis: "Sinto até hoje algo aberto em mim. Sinto dores na minha barriga, sinto alguém mexendo" [sic].

Durante o segundo ano de atendimento, a paciente continuava a relatar novos sintomas durante a sessão. Dessa vez eram esquecimentos, que descrevia como se a mente subitamente apagasse e ela esquecesse para onde estava indo, de onde veio e até mesmo quem ela era. "Era uma coisa tão estranha, como se minha mente apagasse. Sabe um quadro branco? Minha mente apaga e fica como se fosse um quadro branco, sem nada" [sic]. Disse nessa época que estava muito esquecida e não se lembrava dos objetos que colocava em lugares diversos na casa. Fazia questão de assegurar-me que era a primeira vez que um sintoma daquele tipo ocorria. Os sintomas pareciam cada vez se revestirem de uma roupagem diferente e atual no discurso da paciente. A dor de cabeça era apresentada com uma intensidade nova, os desmaios segundo a paciente duravam mais e os esquecimentos eram mais frequentes.

Embora os sintomas assegurem a continuação de uma forma particular da vida autoerótica, na análise, vimos no capítulo anterior como eles se constituem em um modo de sedução, um laço, no qual o paciente tenta capturar o olhar e o desejo do analista. O sintoma de Luzia era como um convite para que eu, como analista, pudesse compartilhar desse gozo, num jogo em que elementos sexuais eram vivenciados através de manifestações que de perto não remetiam de nenhum modo à eroticidade. 
Luzia vinha aos atendimentos para me contar e às vezes mostrar, como no episódio da unha, seu corpo sofredor. Convidava-me a ser ouvinte passiva de seus relatos para assim gozar com ela do erotismo de sua fala, instância essa que também é erotizada pelos sujeitos histéricos. Porém, nota-se que ao longo dos atendimentos houve uma mudança no discurso da paciente em relação aos sintomas relatados, que progressivamente foram se deslocando do corpo. Passou a apresentar uma queixa que estava mais direcionada ao seu mundo mental, às suas emoções, tornando-se nesse sentido mais elaborada.

Ela me relatou mais ou menos nesse período que compareceu a uma consulta com uma ginecologista do sexo feminino, ocasião que a fez sentir-se bastante constrangida. Relata ter dificuldades em se consultar com esses especialistas e submeter-se aos exames. Segundo ela, o motivo do constrangimento deve-se ao fato de Luzia ficar com seu sexo nu e exposto ao toque e ao olhar do médico. Certa vez, em consulta com outro ginecologista, Luzia ficou muito nervosa e irritada quando estava sendo examinada, e ao final da consulta o médico lhe confessou ter tido medo de que ela o agredisse, pois percebera que ela estava muito mobilizada com a situação.

Como afirma Nasio (1991), o corpo do sujeito histérico fica dividido entre a parte genital, excessivamente anestesiada e alvo de inibições sexuais e todo o resto não-genital do corpo, que é extremamente erotizado e superinvestido de excitações sexuais. Quando esse mesmo corpo era observado ou olhado para além da perspectiva de um organismo doente, como quando foi à ginecologista e esta olhou o seu corpo sadio e desnudo, Luzia via nesse olhar algo que a assustava. As crises pareciam revesti-la de uma roupagem que a protegia de ser vista desnuda, com seu desejo à mostra. Assim, ela poderia se defender do confronto com o enigma de sua feminilidade, ao mesmo tempo em que possibilitaria que Luzia tivesse satisfação por meio da atenção recebida pelas pessoas.

Teve um sonho com o pai. Ele estava tranquilo e feliz e Luzia, ao encontrá-lo, disse a ele que estava tudo bem e que ele não deveria se preocupar com ela. Logo em seguida relata outro fragmento de sonho que se seguiu a esse primeiro. Ela estava dentro de um quarto observando um grupo de muitas pessoas fazendo sexo entre si. As mulheres estavam sendo "estupradas", pois os homens as dominavam à força. Luzia não se lembrou de outros detalhes, apenas disse que esse tipo de sonho a fazia 
se sentir muito mal. Digo à paciente o quanto ela parecia repudiar e se sentir também atraída pela violência do sexo e, nas associações que se seguem, ela diz: " $O$ que me atrai? Bom, acho que o que me chama a atenção é a sedução, o interesse que os homens têm pelo corpo delas" [sic].

Nas sessões seguintes. Luzia conta que ao andar na rua onde morava podia ouvir alguns vizinhos dizerem: "Lá vem a louca". Isso a incomodava e perguntava a si mesma por que eles a chamavam de louca, pois não se considerava como uma. De fato, Luzia aparentava ter grande interesse de que seu interlocutor acreditasse que ela era desequilibrada, reforçando o caráter "anormal" do que alegava sentir. "Esse esquecimento não é normal" [sic]. Ao contar sobre quando sonhava, fazia questão de afirmar que não estava dormindo e sim acordada, portanto incluía seus pensamentos e sonhos numa categoria fora da normalidade. Parece haver aqui uma associação que a paciente realizava entre as crises e a loucura. Ser doente e estar fora da normalidade pode responder a um desejo narcísico de diferenciar-se dos demais, de ser especial em sua condição.

Ao identificar-se com a imagem da louca ou da doente, permanece de uma maneira cristalizada na posição daquela que merece cuidados. E mais, a paciente busca com isso fazer a si mesmo um objeto enigmático que convida o outro a desvendá-lo, mobilizando o desejo alheio de conhecer.

Os sintomas da paciente foram se modificando posteriormente conforme o discurso do outro incidia sobre eles, devido à alta capacidade que não apenas ela, mas que os indivíduos histéricos têm de mimetizarem elementos presentes nos diversos âmbitos e discursos. Assim, podemos compreender que como a preocupação de sua mãe revelada à filha a transportou para um lugar no qual ela poderia sofrer algum mal iminente, por conta de seu mal-estar noturno, o diagnóstico de epilepsia e a medicalização modificaram o discurso que tinha sobre si mesmo, passando a considerar-se doente e epilética de fato.

Durante as sessões que tivemos, Luzia apresentava a questão do enigma que envolvia o ser mulher. Dizia que admirava mulheres bem arrumadas, perfumadas e as considerava bastante sedutoras. Às vezes falava da minha roupa, elogiando o que eu estava vestindo. Afirmava, entretanto, que embora admirasse esses elementos femininos eles não lhe diziam respeito, e afirmava que há muito já não se preocupava 
com sua aparência. Esses dizeres da paciente remetiam à questão enigmática da qual os sujeitos histéricos estão envoltos. Porém, para responder à dúvida fundamental da histérica: o que é uma mulher, a paciente procurava seduzir e capturar o desejo dos demais, a única diferença é que para isso lançava mão de outros artifícios, no caso seus inúmeros sintomas.

Contou-me certa vez que seu cachorro teve que ter o pelo do corpo raspado, pois estava com uma forte alergia. Luzia sentiu-se constrangida diante da nudez do cachorro, que não contava mais com os pelos para se proteger. Ficou sensibilizada diante da imagem. Ela então chorou e lembrou-se dos nossos atendimentos. Disse que se sentia nua diante de mim e de si mesma. Nem mesmo a loucura poderia mais ser usada como vestimenta para camuflar ou velar o verdadeiro corpo que se expõe no processo terapêutico.

\subsection{Jỗo}

João, como será chamado neste texto, tem 45 anos, segundo grau completo, solteiro e filho único. Residia com os pais no início dos atendimentos. Foi encaminhado para ser atendido por mim a partir do exame do Vídeo EEG, no qual apresentou um episódio de crise não-epiléptica psicogênica, além de crises compatíveis com o diagnóstico de epilepsia temporal direita, de acordo com informações dadas pela equipe médica. Ele preenchia os requisitos para submeter-se à cirurgia, mas se recusou a realizar o procedimento, pois temia possíveis sequelas. Assim permaneceu sob medicação para controle das crises. Não desenvolvia nenhuma atividade regular ou remunerada, pois fora aposentado por invalidez devido às crises epiléticas que ocorriam desde a infância.

Já no início das sessões foi possível observar algumas características peculiares do paciente. Na recepção do hospital, João era sempre o mais falante, estava sempre interagindo com as demais pessoas e tinha por hábito chegar com muitas horas de antecedência às sessões. Procurava com afinco estabelecer contatos sociais diversos com as pessoas que se sentavam ao seu lado e, à primeira vista, era possível acreditar 
que João tinha grande habilidade para capturar a atenção dos demais. Entretanto, logo surgiram reclamações de outros pacientes a seu respeito na recepção do hospital. Eles diziam que João falava muito alto, chamava a atenção de crianças que não eram suas conhecidas e julgava saber das causas das doenças de todos com os quais ele conversava. João, entretanto, sentia-se particularmente satisfeito quando estabelecia uma conversa com alguma mulher e conseguia obter seu telefone, enquanto aguardava o horário de seu atendimento. Em geral, era a primeira coisa que comentava na sessão, e perguntava-me se eu havia reparado nele, enquanto conversava com as moças na recepção. João, porém, não estabelecia nenhum relacionamento a partir desses contatos iniciais.

João iniciou seu tratamento ainda no Hospital das Clínicas e, além dos atendimentos individuais, ele participava de psicoterapia grupal com outros pacientes epiléticos, grupo este formado por mais três pessoas além de João. Nas sessões em grupo procurava demonstrar que sabia a causa do sofrimento dos demais participantes e como curá-los. Certa vez, em uma das reuniões, uma paciente alegou estar bastante chateada com o fato de que durante todo o tempo que ela permaneceu na recepção, aguardando para entrar na sala de atendimento, João tentou convencê-la de que sua epilepsia tinha por base o fato de que ela dava muita importância ao que os outros diziam a seu respeito, em especial parentes e amigos, e que se ela soubesse controlar isso não teria mais crises. Logo foi taxado de inconveniente pelas pessoas que rapidamente percebiam as incoerências em seu discurso. O paciente dava explicações diversas acerca das inseguranças e angústia apresentadas pelos demais participantes, porém, raramente relatava suas próprias dificuldades.

Costumava chegar com grande antecedência e permanecia na recepção, sempre falando alto e tentando estabelecer uma conversa com alguém. Quando conhecia alguma mulher na recepção, perguntava-me durante a sessão se eu o havia visto conversando com ela ou contava-me que havia dado conselhos para outro paciente que também aguardava na recepção.

Essa insistência em se fazer notar pelos demais parecia demonstrar que João dependia da atribuição de valor pelos outros, para saber sobre sua própria identidade e para saber se tinha os atributos necessários para ser de fato desejado. O paciente apreciava a atenção que recebia dos outros, porém, de maneira paradoxal, acabava 
produzindo um efeito contrário e afastando as pessoas. Nos momentos em que os participantes do grupo revelavam sua insatisfação com João e diziam o quanto o consideravam presunçoso, ele sorria pedindo desculpas, e na semana seguinte mudava o foco de sua ação, procurando um novo paciente, um desconhecido, para dar conselhos que ele julgava verdadeiros e cabíveis a todos. Em alguns momentos, já nos atendimentos individuais, João contou com orgulho que estava no trem, a caminho do hospital, quando começou a conversar com um rapaz, que disse que João era bastante inteligente. Contava com um sorriso: "O rapaz até me disse: puxa, o que você está falando é isso mesmo" [sic].

De acordo com Dor (1993), os homens histéricos procuram ser honrosos, corajosos e reconhecidos por sua bravura, e é por meio dessa imagem valorosa que o histérico direciona sua demanda de amor e reconhecimento. É o próprio João que, em sua simplicidade, nomeou seu desejo em uma sessão: “de ser importante aos olhos dos outros, de conversar com pessoas mais altas do que eu" [sic]. Ser elogiado pelos demais se constituía quase que sua única preocupação, quando estava diante das pessoas.

Nos atendimentos era possível notar o predomínio de uma modalidade de pensamento bastante concreto. Muitas de minhas pontuações e interpretações no início o faziam voltar-se não para seu mundo interior, mas, ao contrário, o mobilizavam a encontrar respostas reais aos problemas de relacionamento que tinha com sua família, como sair de casa, fugir ou arrumar uma mulher. Além disso, seu discurso era extremamente prolixo e tangencial e, por vezes, respondia às minhas pontuações com respostas padronizadas e repetitivas. O paciente também apresentava um modo estereotipado de se movimentar, de produzir pequenos sons antes e ao encerramento das sessões. Outra característica marcante de João era a de que sempre tratava as pessoas como se elas não tivessem nome, referindo-se sempre "àquela amiga", ao "rapaz da esquina" ou "àquela médica lá". Contava-me fatos de um modo pouco esclarecedor, de maneira que era necessário que eu perguntasse sobre mais detalhes, como se ao mesmo tempo quisesse me revelar algo vivido com essas pessoas e ao mesmo tempo esconder.

Com o decorrer dos atendimentos, João começou a perceber como suas atitudes o isolavam dos demais. O paciente relatava com frequência um certo 
sentimento de inadequação. Dizia não saber se comportar, ser muito impulsivo, o que dificultava seu envolvimento com as pessoas. Dizia: "Vivo no mundo dos antigos e preciso viver o que é dos dias de hoje, conversar com jovens" [sic]. Sentia como se não pertencesse a este tempo, relatando o quanto estava cristalizado no passado. Certa vez, a única colega que ele tinha lhe revelou que evitava levá-lo para passear, pois ele não sabia como se comportar direito. "O problema é que eu penso muito rápido. Eu não tenho muito controle e preciso saber me controlar" [sic]. A culpa por agir dessa forma era depositada no pai, tido como responsável por nunca tê-lo ensinado a como ter um comportamento mais adequado e nunca ter tido dele uma palavra de orientação.

João relatou que, na época em que trabalhava como mecânico, procurava seu chefe e superiores para falar sobre suas ideias de como aumentar a produção. Havia uma certa insistência em dar sugestões às pessoas que ocupavam cargos mais elevados, sugestões estas que não eram bem recebidas pelos dirigentes da empresa. Mesmo assim João insistia, tentando demonstrar que era útil, e tinha grande expectativa de obter o reconhecimento de seus pares.

Após receber a aposentadoria por invalidez, João tentou desempenhar algumas atividades, tais como vender canetas, realizar pequenos concertos, montagem de bijuterias; porém, não tiveram continuidade. Ele realizou inúmeras tentativas de efetivar um trabalho, as quais, de maneira geral, resultavam em fracasso ou abandono: "Nunca termino o que começo" [sic].

Afirmava também que não conseguia cobrar pelos pequenos serviços que prestava aos conhecidos. Isso o fazia ficar decepcionado consigo mesmo, pois gostaria de receber pela atividade realizada. Dizia que seu temor era o de constranger quem havia solicitado o serviço. Ter seu valor reconhecido e ser considerado "importante" era o pagamento esperado por João diante de sua tentativa de mostrar-se honroso e bom. Uma interpretação possível sobre as dificuldades do paciente em cobrar pelos pequenos serviços prestados é a necessidade de receber algo que não é da ordem do dinheiro, e sim de uma atribuição de valor. João não aceitava dinheiro em troca dos serviços, mesmo quando solicitado pelo contratante que estipulasse um preço pelo trabalho a ser feito. João logo os oferecia gratuitamente. Na verdade, o pagamento esperado viria sob outra espécie: o reconhecimento de sua generosidade. João se julgava bondoso e sempre pronto a ajudar os demais. 
Como os vínculos que João estabelecia com as outras pessoas em geral eram superficiais e passageiros, sua vida social apresentava-se bastante restrita. Às vezes, João frequentava uma praça, na qual conversava com as pessoas, ia a algumas reuniões na igreja e realizava pequenos consertos para conhecidos, mas, segundo o próprio paciente, essas atividades não tinham continuidade. Se questionava sobre por que nunca terminava o que começava e respondia que precisava de amigos que lhe fizessem companhia e o incentivassem. Ele dizia que sua dificuldade de estabelecer relações mais duradouras e de encontrar uma ocupação era devido ao tipo de criação que tivera. "Tenho dificuldades porque desde sempre nunca tive aquele apoio e hoje não tenho ninguém que possa me auxiliar e fazer as coisas junto comigo" [sic]. Para João, o pai era o grande responsável por suas limitações, devido às duras críticas que recebia e pela falta de apoio. Paradoxalmente, João dizia que o pai o "puxava" quando queria seguir seu próprio caminho.

No início dos atendimentos João se queixava sobretudo de sua família. O pai era alcoolista, descrito pelo paciente como um homem desinteressado pela saúde da esposa, briguento, bruto e incapaz de apoiá-lo em qualquer decisão ou atividade que João se propusesse a realizar. Ele nutria por seu pai um sentimento de grande tristeza e repetia durante as sessões o quanto lhe fazia falta nunca ter tido o apoio do pai para nada. A única preocupação que seu pai tinha, segundo João, era beber em um bar próximo à residência quase todos os dias, e que a mãe, ao invés de ignorá-lo nos momentos em que ele estava alcoolizado, como João achava que ela deveria fazer, cuidava do marido com toda a dedicação e carinho, mesmo recebendo xingamentos e empurrões. Em relação a estes comentários feitos pelo paciente, parece oportuno observar que o discurso de João não se tratava apenas de uma queixa repetitiva e vazia que culpabilizava os pais, mas sim aponta para o fato de João ser capaz de perceber a "loucura" dos pais, demonstrando certa lucidez diante da dinâmica familiar na qual estava inserido.

A mãe era descrita como uma mulher frágil, confusa e chantagista, incapaz de cuidar de si. Ela teve histórico de internação psiquiátrica, porém João não soube informar o que motivou essa internação. Quando contrariada, ela ameaçava se matar com uma faca, ou dizia que o ar lhe faltava e que estava passando mal. Por vezes dizia que iria fugir ou mesmo sair de casa diante de alguma situação de crise. Após dois anos contados a partir do início dos atendimentos, a mãe de João recebeu o 
diagnóstico de Alzheimer. Sua saúde piorava progressivamente e João repetia que o único que poderia cuidar de sua mãe era ele, pois se considerava um filho dedicado, e que, ao contrário do pai incompetente e bruto, estava sempre presente para auxiliá-la.

Ainda quanto ao pai, João dizia que queria ouvir, ao invés de "burro $e$ vagabundo" [sic], palavras de apoio e incentivo que nunca foram ditas. Seu maior sonho era o de tornar-se engenheiro e, assim, segundo ele, passaria a ser valorizado como alguém importante em sua casa, pois alguns parentes muito estudiosos e bemsucedidos tinham toda a atenção da família e eram elogiados pelo pai.

João não tinha contato próximo com os demais membros da família, pois eram julgados como "encrenqueiros e intrometidos", sem exceção. Nutria um sentimento de que o pai amava mais aos demais e valorizava mais os primos do que a ele. João então se esquivava de se relacionar com eles, permanecendo recluso e acusando o pai de não amá-lo o bastante.

O pai de João havia passado para o nome do paciente uma de suas propriedades, mas João colocou como usufruto do pai. Após algum tempo João se oferece para tomar conta da casa, administrando a propriedade, porém seu pai recusou em deixar a propriedade sob sua responsabilidade, o que irritou o paciente em demasia. Ele reclamava dizendo que a casa lhe era de direito, mesmo sendo originariamente do pai. João se esforçava em fazer o pai aceitar suas opiniões, não dar ouvidos a terceiros, e se irritava quando o pai procurava outras pessoas para pedir conselhos. "Ele foi falar com a minha prima lá que já ficou enchendo a cabeça dele. O que ela tem a ver com isso? Eu já falei que ele tem que vir para o meu lado e aí a gente resolve as coisas junto" [sic].

A relação do paciente com o pai era marcada por ataques de ira e ao mesmo tempo de grande demanda amorosa. Dele, João esperava receber o tão sonhado reconhecimento. Insistia em se mostrar útil, em assumir responsabilidades em casa, em consertar, comprar utensílios e estar sempre se fazendo notar ao pai, que segundo João nunca reconheceu seu valor e sempre lhe criticou. Acreditava que nunca recebia o bastante do pai, mas mesmo assim continuava a se esforçar para parecer valoroso aos seus olhos. Em inúmeras situações, João apresentou crises de cólera chegando por vezes a tentativa de agressão, que inicialmente eram justificadas por ele devido ao mau comportamento do próprio pai. 
Acessos de ira são descritos como uma manifestação marcante dos histéricos homens, ao lado dos sintomas conversivos, que em sua função e sintomatologia são comparáveis às conversões das mulheres histéricas. As crises de ira que João tinha pareciam revelar uma dupla significação: ele não se considerava amado o bastante, julgava-se indesejado e excluído pelo pai, mas, em um sentido oposto e talvez concomitante, está a figura da mãe, que acolhe o pai e também o exclui em certa medida, quando cuida do pai.

Quanto à vivência de sua sexualidade, João gostava de seduzir as mulheres, mas as suas relações sexuais ocorriam grande parte das vezes com prostitutas. Dizia ser difícil se aproximar das demais mulheres, uma vez que elas eram interesseiras e queriam apenas dinheiro. Certa vez ele me contou bastante contente que uma das prostitutas havia lhe dito que ele era carinhoso e que não entendia porque ele estava sem ninguém, o que muito o agradou, ficando feliz com o elogio. Em outra ocasião, uma outra prostituta com quem tinha relações esporádicas o levou a um centro espírita na tentativa de auxiliá-lo em sua timidez e dificuldade de relacionamento, mas João, após algumas visitas ao lugar, decidiu não ir mais.

Com as mulheres em geral, sentia subitamente seu desejo desaparecer quando estava prestes a penetrá-las. Nas palavras do paciente, elas, que antes eram atraentes, se tornavam feias e desinteressantes antes da consumação do ato sexual. Também relatou ter impotência, que segundo Dor (1993) se constitui como a prova pública de seu amor e fidelidade à mãe. A impotência de João seria então uma maneira de afastar os conteúdos edípicos e perpetuar essa ligação com a mãe. Além disso, João lembrava da mãe nos atos sexuais, o que pode ser compreendido como uma tentativa de anular o prazer que pode ser obtido com uma outra mulher. E também, quanto mais próximos da consciência de João ficavam seus desejos, no ato sexual, mais impossibilitado ficava de penetrar a mulher.

João procurava o amor de todos, mas de fato era apenas um simulacro de amor, já que o encontro real com a sexualidade de uma mulher lhe era impossível diante da fidelidade prometida à mãe. Como alternativa João procura dessexualizar a mãe, tomando-a como figura pura e única. Com uma mãe dessexualizada, João pode fantasiar com uma eterna união com a mesma sem sofrer as retaliações vindas de seu 
pai. Tal como afirma Bollas (2000), as dimensões sexual e edípica são suprimidas e a mãe emerge como um ser casto e venerável.

O paciente dizia que queria poder conquistar uma mulher mais jovem e bonita, mas nenhuma parecia ter os atributos necessários para satisfazê-lo. Entretanto, imaginava com frequência a cena na qual ele apresentaria uma mulher jovem e bonita ao pai. João procurava, dessa forma, obter do pai o reconhecimento de seu valor enquanto objeto de desejo de uma mulher e é por meio de uma "mulher bonita" que ele acreditava poder obter de seu pai a aprovação de seus atributos. Essa mulher seria apenas um instrumento que possibilitaria, na fantasia do paciente, receber do pai seu reconhecimento e amor.

Há alguns anos ele conheceu uma mulher com quem decidiu morar junto, em uma pequena casa, mas, segundo ele, a mulher dava muita importância ao dinheiro e não aceitou viver com o pouco que João recebia. Descreveu assim o fim de seu relacionamento: "Conheci uma mulher lá. Aí decidimos morar junto. Então ela queria dinheiro, dinheiro, dinheiro e eu mandei ela pra lá" [sic]. Após o rompimento, João voltou a morar na casa dos pais, o que o paciente justificava como sendo motivado pela insistência deles. Sublinhava que ele mesmo não queria esse retorno. Não lamentava a separação e dizia nos atendimentos: "Mulher igual minha mãe eu não vou encontrar. Mulher pra fazer as coisas junto, resolver os problemas junto. Além disso, eu gosto de mulher nova, não de velha" [sic].

Em uma das sessões, ele me diz que nas ocasiões em que marcou de se encontrar com uma mulher, não conseguia se esquivar de pensar em sua mãe, em como ela estaria em sua ausência. "Quando saía de casa ficava pensando na minha mãe, que ela precisava de mim, e aí eu sentia uma vontade de voltar" [sic]. Lembrava de sua mãe dizendo que ele era tudo para ela e sente-se dividido entre deixá-la só e encontrar-se com outra mulher. Quando ainda era adolescente, certa vez João marcou um encontro com uma menina no metrô, e, enquanto aguardava por ela, percebeu que o vidro que recobria o mostrador de seu relógio caiu no chão e quebrou. Esse relógio havia sido um presente do pai, igual ao que ele mesmo usava. João entristeceu-se e foi tomado por um desânimo e um desinteresse instantâneos pelo encontro. Foi embora, voltando para casa e pensando que seu pai brigaria com ele por causa de seu descuido 
com o vidro do relógio, sem nunca saber se a moça por quem estava interessado foi encontrá-lo ou não.

Quando uma prostituta lhe disse que ele era especial, romântico e que havia "poucos homens gentis como ele" [sic], com um sorriso nos lábios, João expressa satisfação por ter sido considerado como um homem desejável aos olhos da mulher. Segundo Dor (1993), o sujeito histérico não consegue engendrar-se genuinamente em uma relação, não avançando para além do jogo de sedução. Interessa ao histérico ser amado por todos, mesmo que isso lhe imponha sacrifícios, pois ele procura seduzir tentando negociar o amor, mas tal como na histeria feminina o histérico é incapaz de viver com profundidade um relacionamento amoroso. A sedução seria então um fim em si mesma.

No episódio relatado, no qual João volta para casa antes de ser abordado pela moça que estava indo encontrá-lo, nota-se uma clara tentativa de retorno às figuras parentais, diante da possibilidade de um encontro amoroso. Sobre esse respeito, ainda conforme Dor (1993), o sujeito histérico realiza um pacto com a mãe, pacto este que é o de não abandoná-la e só a ela devotar seu amor. Os fracassos nas relações amorosas são como testemunhos à mãe de que nunca será substituída por nenhuma mulher que mobilizará seu desejo. João, ao esquivar-se do encontro genuíno com uma mulher enquanto objeto de seu desejo, tenta assegurar que esse pacto com a mãe não seja rompido, deixando claro em seu discurso que não há mulher como ela. A cena relatada sobre o encontro que nunca foi efetivado na estação, quando João volta para casa antes de encontrar a mulher, é uma imagem que remete ao desencontro do sujeito histérico com seu próprio desejo e com o desejo do outro.

Em um determinado momento o pai do paciente ligou para mim. Aparentando ser uma pessoa bastante humilde, contou-me sobre sua preocupação a respeito do filho e de seus repentes de agressividade. Disse que João reclamava sem parar, brigava com ele e às vezes tentava agredi-lo, sendo que algumas vezes a polícia foi chamada para apaziguar os ânimos. Conversamos sobre isso na sessão e João me contou que uma prima que estava visitando seus pais perguntou ao paciente onde guardavam o macarrão, pois ela queria preparar um almoço para os pais dele. Ele não soube dizer onde estava o macarrão e ficou irritado com a idéia de que "não sabia de nada em sua casa” [sic]. Ao ver o pai e a mãe juntos no quarto de casal, correu ao encontro dos 
dois que estavam trancados no quarto. João não pôde entrar e bateu na porta enraivecido. Se vendo frustrado e excluído uma discussão foi iniciada e o paciente tentou agredir o pai. João dizia não estar bem certo do porquê de suas atitudes explosivas em relação ao pai e logo em seguida demonstrava estar arrependido. Dizia na sessão: "Por que ele não me deixa viver a minha vida?" [sic]. A polícia foi chamada e os policiais, percebendo que se tratava de uma briga de família (não era a primeira vez que a polícia havia sido acionada em uma discussão na casa de João), disseram para que ele ficasse em algum lugar durante a noite e voltasse para casa no dia seguinte, já que não iriam prendê-lo.

João então se lembra que essa prima convidou o pai de João para morar no interior com ela e os demais parentes. Seu pai estava pensando sobre essa possível mudança, o que deixava João bastante descontente, pois temia ficar só. "Essa prima se intromete muito" e acrescentava: "Meu pai que morar lá com ela, que vá então e me deixe aqui" [sic]. Falava isso em um tom de raiva e tristeza. Entendendo as possíveis implicações inconscientes para os atos explosivos de João, não descartei a possibilidade de que a impulsividade e a agressividade direcionadas ao pai pudessem ter sido catalisadas pela condição médica decorrente de interações medicamentosas e até mesmo acentuadas pelas características de seu tipo de epilepsia.

Elementos sadomasoquistas parecem presentes na relação estabelecida pelo pai e João. O paciente, embora se queixasse das brigas frequentes existentes em sua casa, procurava sempre estar envolvido nesses episódios e seu contato com o pai por vezes era marcado por agressões verbais e físicas. Essas discussões alimentavam João, de modo que muitas vezes ele mesmo agia como provocador da ira paterna, quando revelava uma informação particular ao pai mesmo sabendo que isso desencadearia uma discussão. Fazia isso também para que depois João pudesse "atacar" a pessoa do pai, desmerecendo-o e desvalorizando seus atos. Essas brigas tinham um caráter repetitivo, e compreendo que elas estavam a serviço de uma necessidade de punição direcionada ao próprio paciente, motivada por seu desejo inconsciente parricida, como também parecem remeter à realização regressiva do desejo passivo amoroso direcionado ao pai. Segundo Dor (1993), o amor pela mãe, pelo pai e o desejo de eliminá-lo coabitam de forma recalcada no inconsciente, e constituem a base do sentimento de culpa e punição. 
Para Alonso \& Fuks (2004), a questão do parricídio na obra freudiana está inserida em uma problemática mais geral do Complexo de Édipo. Para o menino, a relação com o pai é ambivalente: ele quer ser como o pai, mas também procura eliminá-lo. O desejo de eliminá-lo abre a possibilidade de uma punição desse mesmo desejo, sob a forma de castração, associada ao desejo concomitante de possuir a mãe. Ambos são recalcados para que se preserve a virilidade. Esses desejos perduram no inconsciente e se constituem na base do sentimento de culpa.

Embora se tornar "mais importante" aos olhos do pai era seu objetivo, o paciente temia grandemente ser o alvo de um pai agressivo, que poderia imaginariamente liquidá-lo, caso ele se destacasse e o superasse de certa forma. Para proteger-se dos ataques imaginários do pai diante de seu desejo edípico pela mãe, uma saída possível é adotar a posição feminina, no qual a presença de uma bissexualidade o possibilitaria escapar dos ataques do pai (Dor, 1993). Assim, ele ocupa o lugar da mãe para que, ao invés de ser odiado, possa ser amado pelo pai. Nota-se a esse respeito a insistência em ser valorizado pelos homens, o desejo que eles o reconheçam como valoroso. Se amar a mãe é ameaçador, pois o pai pode voltar-se contra ele e castrá-lo, amando o pai, ele permanece em uma posição livre da ira paterna e distante da angústia de castração.

Enquanto ele contava sobre o episódio da briga, e após ser convidado a pensar no ocorrido, João diz: "Não fale mais sobre isso, pois senão eu vou ter aquilo lá. Você está reparando que eu estou ficando diferente?" [sic]. Logo em seguida João começou a se movimentar na cadeira e parou de conversar. Parecia que ele estava tendo uma crise, exatamente no momento em que estávamos falando sobre ser preterido pelo pai. Ele não caiu no chão, apenas apoiou-se na minha mão, e, confuso, levantou-se alguns minutos após, pegou e soltou sua agenda que estava sobre a mesa, fez o mesmo com minha bolsa que estava sobre a mesa, e quando eu o chamei pelo nome apenas fazia sinal de não com a cabeça. Por fim, sentou-se em outra cadeira que estava disponível na sala, e, após alguns momentos de silêncio, fechou os olhos, olhou para o relógio e disse: "Acho que dormi. O que eu estou fazendo nesta cadeira?" [sic]. Explico que eu acabara de presenciar, então ele passa a dizer repetidamente que não sabe por que passou mal. Pergunto se ele lembra do que estávamos conversando antes. Ele diz que não e permanece dizendo que não sabia por que ele tinha tido um ataque. Retomo o que estamos falando. João, em uma postura de aparente descaso, diz que sua família 
nunca foi importante, ele estava nervoso com outras coisas, que não tinha nenhuma relação com o que estávamos falando na sessão.

Esse evento foi uma clara interrupção do trabalho associativo do João e o colocou em um estado no qual havia apenas a ação e não mais o recordar. O sintoma aparece no lugar onde deveria haver a recordação de um conflito ou pelo menos de partes de seus elementos. Pode-se entender que, nesse momento, a suposta crise foi um ataque ao processo analítico, uma vez que o trabalho da livre associação e interpretação foi interrompido. Além disso, a crise foi resultado de uma interpretação que posicionou o paciente no lugar de sujeito responsável e implicado em seu sintoma, e não mais objeto. Ao ser convidado a responder desse "outro lugar", lugar de responsabilização por seu próprio desejo, o paciente reagiu buscando novamente o lugar de objeto por meio da crise.

Outro aspecto importante foi que essa crise ofereceu a possibilidade de João ter seu corpo olhado e tocado por mim - eu o segurei pela mão, quando este escorregava da cadeira. Foi como que uma tentativa de erotizar o espaço analítico, de estabelecer um contato comigo que passava diretamente pela via da excitação corporal e não mais por meio das palavras.

João realizava algumas tentativas de desvincular-se de sua família. Em geral isso ocorria após uma discussão. Ele contava que saía de casa mas voltava um ou dois dias depois, pois não suportava viver sem aquilo que constituía o centro de sua vida: a vida dos pais. "Hoje eu saí de casa, só voltei de noite. Quase que eu não volto pra casa einh?" [sic]. Ele parecia tentar me convencer que era capaz de deixá-los.

No ano de 2008 perdeu sua mãe, que faleceu em decorrência da doença de Alzheimer. Foi um período de grande tribulação e tristeza. O paciente dizia que daquele momento em diante ele e o pai precisariam se entender, e que teriam que dar força um ao outro. Sentia pena de seu pai, que lamentava muito a falta da mulher. João ausentou-se de algumas sessões nesse momento, mas sempre ligava para me avisar que não poderia comparecer ao atendimento, pois precisava cuidar da documentação do inventário. Tinha medo de perder o direito de frequentar os atendimentos devido ao número de faltas, o que a mim me parecia estar relacionado ao quanto ele considerava importante nossos encontros. 
João solicitava a presença do pai: "Meu pai tem que vir para o meu lado e resolver as coisas comigo. Desde pequeno ele me prendia, aí faltou aquela confiança da minha parte de pegar e sair" [sic]. Dizia ainda que por causa das críticas do pai nunca pôde terminar as tarefas que começava e que por isso, nunca pôde progredir na vida. Seu pai, no discurso do paciente, era como alguém terrivelmente poderoso, o grande responsável pelo rumo que a vida de João tinha tomado, mas também aquele que não correspondia ao seu amor.

Com o decorrer dos atendimentos a imagem do pai como responsável por seus males foi progressivamente sendo desconstruída e o paciente deixou de culpabilizá-lo por seus dramas. De maneira inesperada, alguns meses depois do falecimento da mãe seu pai tem um acidente vascular cerebral e perde os movimentos do lado esquerdo do braço. Ele ficou bastante debilitado e João então assume a responsabilidade de visitálo no hospital e cuidar da casa. O pai não resiste e falece alguns meses depois. João tem uma crise de angústia durante uma noite, quando é levado ao hospital de ambulância. Ele falta na sessão seguinte e liga para me contar o motivo de sua ausência. Conta o ocorrido ao telefone e me diz que os médicos alegaram que o ocorrido fora motivado por "causas emocionais".

A morte dos pais significou entre outras coisas, o encontro com a dura realidade de que a eternidade não existe e a dimensão de uma vida separada das vidas dos pais tornou-se bem presente, porém assustadora. A morte do pai pode ter reativado impulsos inconscientes agressivos direcionados a ele, e como consequência a crise de angústia ocorreu.

No segundo ano de seu tratamento, após a morte dos pais, João começou a namorar. Com a namorada o paciente estabelece um vínculo mais estreito. Passou a apreciar sua presença, começou a desenvolver mais atividades sociais, mas relatava dificuldades para se relacionar sexualmente com ela. Disse que se lembrava da mãe na hora do sexo e visualizava diante de si a expressão grave do rosto do pai. Dizia que gostava de ficar conversando por horas antes da penetração, considerava uma demonstração de carinho, mas percebe apenas num segundo momento que tentava evitar o contato sexual por meio das longas conversas que tinha com a namorada.

O relacionamento com essa mulher prossegue e eles passam a viver juntos depois de algum tempo de namoro. João então passa a relatar um desânimo 
generalizado em realizar os afazeres domésticos. Mesmo sabendo que deveria auxiliar sua namorada, ele entrega a ela a tarefa de cuidar das coisas que antes sua mãe se ocupava. Sua companheira o faz lembrar de quando sua mãe vivia. João falava que se lembrava do cuidado da mãe pela casa e de como ele era cuidado por ela quando João tinha alguma crise. Em uma das sessões o paciente comete um ato falho dizendo que queria perder os sentidos, ao invés de dizer que perdia os sentidos com a namorada. Ao tentar se explicar, fala dos cuidados que recebeu dela quando "perdeu os sentidos" [sic], cuidados estes que o paciente relaciona aos recebidos da mãe. Quando sentia preguiça para realizar as tarefas domésticas nesses momentos a namorada assumia os serviços da casa. Ele reconhecia que esse sentimento de preguiça o impulsionava a esperar que a namorada cuidasse do que fosse preciso. A associação com a figura da mãe é inevitável, uma vez que o paciente afirma que a namorada ocupa um lugar muito parecido com o lugar que outrora fora ocupado por sua mãe, o de cuidadora, não apenas do lar, mas dele João.

O paciente produz associações que ligam aquilo que ele denomina de crises à atenção, cuidado e consideração da namorada. Expressa um desejo de retorno à satisfação dos cuidados maternos ao mesmo tempo que apresenta dificuldades na vivência da sexualidade com a namorada. O paciente dizia por vezes que sabia diferenciar quando as crises eram "psicológicas", como ele assim as definia, e quando eram causadas por sua epilepsia. Essa diferenciação que o paciente realizava é bastante curiosa e interessante, pois implica já em um certo reconhecimento de que elementos de seu mundo interior seriam atuantes em suas crises.

Nas sessões, em algumas ocasiões ele chamava minha atenção dizendo: "você está percebendo que eu estou ficando confuso?" [sic]. Era como se eu precisasse olhar e saber que uma crise seria iminente. Nisso se evidencia o desejo do paciente em mostrar seu corpo a mim, de se deixar capturar por meu olhar. Questão central na histeria que dá a ver seu corpo e que seduz e sofre por meio dele.

Ocorre, algumas sessões seguintes, o que ele denomina de segunda "crise". João fecha os olhos, começa a dizer o quanto me achava atraente e que estava pensando em me convidar a tomar um café. Sua feição se altera e ele tem um sorriso pouco espontâneo no rosto enquanto me diz que gostaria de me convidar para sair. Ele afirma, entretanto, que só está conseguindo falar essas coisas, pois está inconsciente. 
Curiosamente ele se mostra sem inibições para referir esses conteúdos e ele não me parece inconsciente de fato. Naquele momento, algo da forma que ele utilizava para seduzir as mulheres, segundo ele inconscientemente, se fez muito presente no espaço transferencial da análise. João já havia me dito que ficava em dúvida em dizer-me certos assuntos, pois me considerava "importante e bonita" [sic], mas naquela sessão ele revelou seus desejos de modo mais explícito, e recorria a esse estado que o possibilitava dizer tudo o que queria sem se comprometer. De fato, João sempre afirmava que era comum perder os sentidos ao se aproximar das mulheres com quem ele queria ter um caso. Dizia ainda que chegava a perder a consciência e acordar às vezes tendo relações com essas mulheres.

Embora não possamos afirmar que se trataram de crises genuínas ou não, à luz da psicanálise devemos analisar esses eventos levando em consideração o setting e a transferência. Um sintoma na transferência se transforma em sintoma analítico, portanto passível de ser analisado. Os desejos que João tinha a meu respeito foram revelados sem pudores quando diz ter perdido a consciência e em seguida me convidar para tomar um café. Curiosamente ele afirma que essas revelações só eram possíveis quando ele se encontrava inconsciente. O que o paciente chama como crise nesse momento e no setting parece ser esse estado de consciência que torna possível a exposição dos conteúdos que poderiam constrangê-lo, caso assumisse dizê-los conscientemente. É uma perda temporária de inibições interpretada pelo paciente como perda de consciência. Assim, percebe-se que essa aparente dissociação é para João a possibilidade de se expor conteúdos eróticos sem assumi-los de fato. Valendose da crise, ele pode revelar conteúdos que não são ditos quando está lúcido. O paciente utilizava a perda temporária de inibições como possibilidade de tentar me seduzir, pois para João, naquele momento eu era supostamente aquela que poderia responder sobre seu valor enquanto homem. Talvez esperasse que eu lhe respondesse se ele poderia ser querido por mim, se tinha atributos que pudessem me atrair. Ele questiona e procura obter de mim o reconhecimento de seu valor enquanto objeto causa de desejo. Aí está posta implicitamente a questão central da histeria: Quem sou eu? Como posso me definir?

Se considerarmos que a crise expressa um conflito de natureza sexual, quais são os elementos que a constituem? Tomando a crise como uma formação de compromisso que visa satisfazer um desejo proibido, ela seria então correspondente a 
uma satisfação sexual direcionada a figura da mãe e também ao pai. Em última análise, a crise de João expressa o desejo inconsciente de união com as figuras parentais ao mesmo tempo em que o protege contra a angústia da castração. Dessa forma, nota-se que há, como afirma Bollas (2000), a erotização do espaço analítico, tão característica dos histéricos, que é feita por João nesse momento através de seu sintoma crise. A erotização do setting produzida por João poderia ser considerada como um substituto da tentativa de erotização da relação parental, da qual ele se vê excluído. A crise de João se configura como uma forma de burlar o pacto de fidelidade com a mãe, pois o desejo e o gozo estão irreconhecíveis e disfarçados sob o colorido de uma doença genuína, uma crise epilética.

A crise também aparece como um elemento que possibilita expressar o desejo por outra pessoa, que não o pai e a mãe, de um modo disfarçado e, portanto, mais aceitável. É ao mesmo tempo uma forma de burlar o pacto de fidelidade do paciente com os pais como também uma forma de reafirmar esse pacto, pois o sujeito histérico resiste em assumir desejos relacionados a outros objetos de investimento afetivo. Vemos isso em João que apresenta dificuldades em se desvencilhar dos pais enquanto objetos de amor absolutos. O paciente sonhava em poder conquistar uma mulher bonita para apresentar ao pai e obter dele a aprovação, na tentativa de fazer da "mulher bonita" um instrumento para conquista do amor do pai, verdadeiro alvo das investidas afetivas do paciente. Esse amor ao pai pode ser compreendido como uma proteção contra a angústia de castração, decorrente da ameaça imaginária da punição que poderia sofrer diante dos desejos edípicos nutridos pela mãe. Querer ser amado por ele pode ser uma forma do paciente defender-se dos seus ataques.

Sinto como se o paciente procurasse me convencer de seus atributos, revelando, em negativo, as incertezas que ele nutria em relação à sua identidade e à sua posição como aquilo que tem valor para o outro. E ser desejado também é uma grande preocupação que João expressa no setting analítico. Durante os atendimentos sou aquela que deve dar crédito às suas virtudes e é a mim que ele diz, bastante satisfeito, que é um homem capaz de agradar uma mulher. Por um lado ele se queixa de suas limitações: não consegue estudar, não termina o que começa, não sabe conversar; e por outro quer definir-se como um homem sedutor, que possui a admiração de todos. É um mito que o paciente constrói que parece ser fruto de uma colagem de vários aspectos que o paciente acredita ter valor para os demais, como 
usar boas roupas, ter um bom cargo, ter mulheres bonitas e resolver os problemas dos demais. Esse homem mítico é uma construção destinada a resolver a questão central da histeria que envolve sua identidade e seu valor como objeto de desejo do outro. Ao se apegar a crença de que é possível tornar-se esse homem completo e perfeito, o paciente afasta de si a angústia decorrente da lógica na qual todos estamos inseridos, que é a lógica da finitude, da incompletude e, portanto, da castração. Esse homem idealizado e sem defeitos no qual o paciente procura se transformar parece estar posicionado em um nível diferente do ser humano, pois ele não estaria submetido às agruras da imperfeição, das lacunas, do desconhecido. Ora esse ser é encarnado no pai, ora no executivo de cargo elevado. É especialmente ao pai que ele se direciona para obter a resposta de como se tornar esse mito, no qual a castração não se faz presente. Como o pai não lhe responde, torna-se alvo de sua ira e de sua constante reivindicação. 


\section{CONSIDERAÇões Finais}

As crises não-epiléticas psicogênicas são condições que desafiam a prática médica atual e que se beneficiam de um entendimento multidisciplinar para sua melhor compreensão e tratamento. A psicanálise pode oferecer sua contribuição, uma vez que se ocupa em estudar os processos inconscientes e sua relação com os sintomas. Neste trabalho, consideramos a possibilidade de uma articulação entre as dimensões orgânica e psicodinâmica, compreendendo o sujeito de maneira integral.

A dissociação e a conversão são mecanismos descritos como constitutivos das crises, mecanismos estes que também são encontrados na histeria, o que sugere uma associação entre ambos. Partindo dessa hipótese, foi possível verificar nos casos relatados que as crises ditas psicogênicas, enquanto fenômenos conversivos, têm uma significação inconsciente e estão relacionadas a conflitos e fantasias que são desconhecidos pelos próprios sujeitos. No primeiro caso estudado a paciente não reconhecia as crises como sinais ou sintomas vinculados à sua vida emocional, rechaçando a ideia de que elas poderiam estar relacionadas com seus elementos psíquicos particulares. Já no segundo caso, o paciente associava às crises questões de ordem subjetiva e não apenas orgânicas, afirmando até que podia discriminar as crises motivadas por questões psicológicas daquelas que ele chamava de epiléticas. Pode-se concluir que cada um dos pacientes adotou uma posição bastante distinta em relação aos seus próprios sintomas, embora em ambos os casos inicialmente houvesse uma recusa dos sujeitos em questionarem esses ataques à luz do conteúdo de suas associações e à luz das fantasias e desejo implicado nesses sintomas.

Há diversos aspectos que puderam ser observados nos casos e que se relacionam à ocorrência das crises. O primeiro é o de que as crises são sustentadas e engendradas por fantasias inconscientes, que estão na origem da formação desses sintomas, como a fantasia de uma infância assexuada e a fantasia de permanecer para sempre vinculado às figuras parentais. Essas fantasias parecem servir justamente para encobrir conteúdos de natureza sexual presentes já na infância, e que são conflitantes para o sujeito. Dessa forma, a própria problemática sexual da histeria parece ser o que sustenta e mobiliza as crises psicogênicas nos casos estudados. 
O segundo aspecto a ser considerado é a possibilidade das crises recorrentes servirem como descarga imediata de afeto, produzindo, pela mera repetição, uma satisfação ligada à compulsão. Elas vinculam um gozo do qual o paciente se vê incapacitado de recusar. Além disso, as crises possibilitaram ganhos secundários bastante evidentes, retirando do sujeito a responsabilidade em conduzir uma vida produtiva com seus desafios, ausências e frustrações. As crises aparecem onde o paciente não consegue assumir seu próprio desejo, como uma tentativa de fazer com que permaneçam no lugar de objeto, e assim evitar a responsabilização subjetiva pelo sintoma e sofrimento pelos quais se queixam.

O caráter repetitivo das crises parece funcionar como instrumento da resistência, pois age como um convite constante para que tanto paciente quanto o analista se prendam à concretude das manifestações corporais, abandonando assim o empreendimento da busca de significações. Isso se evidencia quando o fluxo de associações é prontamente interrompido pelo relato de alguma queixa orgânica ou de algum ataque, ou até mesmo, no caso do segundo paciente, quando no meio do trabalho analítico interrompe nossa conversa e tem um ataque que, segundo ele, o faz perder os sentidos.

No caso em que foi relatado um histérico do sexo masculino houve a ocorrência de diversos episódios de ira direcionados à figura do pai. Mesmo considerando que episódios de agressividade do paciente pudessem ser motivados pela condição prévia que a epilepsia impunha, é evidente que houve uma "escolha" em relação ao objeto alvo de sua agressão, escolha essa modulada e exacerbada por conflitos que estavam sendo elucidados na sessão analítica.

Também foi possível observar que ambos os pacientes procuraram erotizar o setting analítico. No primeiro caso a paciente utilizava seu discurso e seu relato sobre seus sintomas corporais como modo de sedução. Contar sobre seu corpo sofredor constituía em um modo de prazer autoerótico, um prazer que se encerrava na ação de contar e de me impactar com o que dizia. O segundo paciente erotizava a sessão ao convidar-me para olhar para seu corpo, quando ele estava, segundo ele mesmo, prestes a ter uma crise durante o atendimento. Havia sempre uma ameaça de que ele estava ficando vermelho, que sua cabeça rodava, que estava confuso e que se seguia de uma pergunta: "Você está vendo o que está acontecendo comigo? [sic]. De fato também a primeira paciente, mostrou-me sua unha do pé encravada e justificou sua falta à sessão 
por esse motivo. Dessa forma, foi possível notar que a questão do "dar a ver" o corpo tão presente na histeria, se constituiu em um mecanismo bastante presente na relação que esses pacientes estabeleceram comigo, durante os atendimentos.

As crises são como movimentos que tentam capturar o olhar do outro para um corpo dessexualizado, constituindo dessa forma um gozo autoerótico. Nos dois casos estudados há um desejo de seduzir o outro e de se exibir a ele, em especial por meio de seus corpos. Entretanto, eles relatam dificuldades no nível do estabelecimento das relações amorosas. No primeiro caso a paciente sublinha a insatisfação que sentia estando ao lado do marido. Ela idealizava uma relação romântica e sem desejo sexual. No segundo caso, por um longo tempo o paciente só conseguia ter relações sexuais com prostitutas, alegando perder os sentidos quando estava interessado nas demais mulheres, embora ele quisesse muito impressionar a todas e se agradasse quando recebia um elogio. Assim se observa nos relatos dos pacientes a característica descrita pelos autores estudados neste trabalho: a sexualidade do histérico é na verdade um simulacro de sexualidade, ainda vinculada a satisfações infantis de caráter autoerótico.

A crise então aparece como uma forma possível de contato no qual o erotismo está disfarçado. É uma formação que satisfaz à medida que possibilita ser alvo do cuidado do outro, resquício de um prazer ligado aos cuidados primeiros recebidos pela mãe. A crise também se configura como a expressão do pacto que o histérico realiza com a mãe, de ligar-se a ela completamente e de não prosseguir no desenvolvimento de sua sexualidade. Uma outra leitura possível é a de que por meio das crises, o corpo do sujeito histérico pode burlar esse pacto, entregando-se ao erotismo com o outro de maneira disfarçada e descompromissada, o que seria uma forma rudimentar de incluir o outro sem abrir mão da fidelidade aos pais.

As crises parecem estar ligadas a repetição, a um excesso que não deixa de se inscrever no corpo. A esse respeito não se pode esquecer que os sintomas são formas de obtenção de satisfação pulsional, e é no corpo do histérico que essa satisfação encontra seu lugar. Retomando o conceito desenvolvido por Lacan, existe um gozo que liga o sujeito ao seu sintoma. Assim sendo, o trabalho do analista não se reduz apenas à descoberta e interpretação das significações inconscientes do material das sessões. O percurso da análise implica em um novo posicionamento do sujeito em relação ao gozo que o ancora em seu sintoma. 
Inúmeros questionamentos e reflexões me ocorreram enquanto realizava este trabalho. Um deles diz respeito à uma possível associação entre histeria e masoquismo, em que medida seria possível fazer essa aproximação tendo em vista que ambos se utilizam do corpo como forma de gozar. Outra questão suscitada pelo trabalho e que merece um estudo mais aprofundado é a manifestação sintomática da histeria masculina por meio dos ataques de cólera, descrito por Dor. Seria interessante pensar de maneira mais detalhada de que forma esta crise de cólera se constitui como sintoma para o sujeito histérico do sexo masculino.

Por fim, cabe ressaltar que, quer hajam significações inconscientes evidentes que impliquem o sujeito em suas crises, quer elas sejam consideradas uma condição determinada por componentes predominantemente neurológicos, não é prudente esquecer que psiquismo e físico se apoiam mutualmente. Uma pessoa que apresenta uma condição orgânica também é passível de ser analisada, pois o que interessa ao analista é a rede de significações inconscientes que relaciona o sujeito à sua doença. Sob essa perspectiva, a necessidade de uma diferenciação de uma crise epilética genuína ou motivada por elementos psíquicos não se apresenta como condição para a realização de um tratamento psicanalítico. Há espaço na análise para todos os dramas humanos, quer estes incluam a presença de uma doença ou não. 


\section{REFERÊNCIAS}

Aguiar, F. (2001). Método clínico: método clínico? Psicol. Reflex. Crit., Porto Alegre, 14(3), 609-616.

Alonso, S. L., Fuks, M. P. (2004). Histeria. São Paulo: Casa do psicólogo.

Ambertín, M. G. (2006). Imperativos do supereu: testemunhos clínicos. São Paulo: Escuta.

Aldenkamp A. P., \& Mulder O. G. (1997). Behavioural mechanisms involved in pseudoepileptic seizures: a comparison between patients with epileptic seizures and patients with pseudo-epileptic seizures. Seizure, 6(4), 275-282.

Baillés, E., Pintor L., Fernandez-Egea, E., Torres, X., Matrai, S., de Pablo, J., \& Arroyo, S. (2004). Psychiatric disorders, trauma, and MMPI profile in a Spanish sample of nonepileptic seizure patients. Gen Hosp Psychiatry, 26(4), 310-315.

Betts, T. (1999). Non epileptic seizures (pseudoseizures). In: J. S. Duncan, S. J. M. Sisodiya, \& J. E. Smalls (Eds.). Epilepsy 99: from science to patient. Oxford: International League Against Epilepsy.

Benbadis, S. R., Lacman, M. E., King, L. M., \& Swanson S. J. (1996). Pré-ictal pseudosleep: a new finding in psychogenic seizures. Neurology, 47, 63-67.

Bergeret, J. (1988). Personalidade normal e patológica. Porto Alegre, RS: Artes Médicas.

Birman, J. (1994). A direção da pesquisa psicanalítica. In: J. Birman. Psicanálise, ciência e cultura (pp. 13-27). Rio de Janeiro: Jorge Zahar Editor.

Bollas, C. (2000). Hysteria. São Paulo: Escuta.

Camargo, J. F., \& Mello Neto, G. A. R. (2006). Discurso psicanalítico pós-freudiano sobre a histeria e algumas relações com a literatura. Aletheia [online], (24), 81-93. Recuperado em 27 de outubro, 2009, de http://pepsic.bvspsi.org.br/scielo.php?script=sci_arttext\&pid=S141303942006000300008\&lng=pt\&nrm=iso 
Cohen, C., Ferraz, F. C., \& Segre, M. (2006). Saúde mental, crime e justiça (2a ed). São Paulo: Edusp.

Cukiert, M. (2000). Avaliação psicodinâmica de pacientes com crises pseudo-epilépticas. In: A. Cukiert. Tratamento clínico e cirúrgico das epilepsias de difícil controle (pp. 213216). São Paulo: Lemos Editorial.

Damásio, A. R. (2001). O erro de Descartes: emoção, razão e o cérebro humano. São Paulo: Companhia das Letras.

David-Ménard, M. (1989). O corpo: Uma questão crítica para a psicanálise. In: M. Augé et al. O objeto em psicanálise (pp. 73-106). Campinas, SP: Papirus.

Dor, J. (1993). Estruturas e clínica psicanalítica. 2. ed. Rio de janeiro: Taurus Editora.

Engel, J., \& Stern, J. (2004). Psychogenic seizures. Recuperado em 15 de maio de 2009, de http://www.medlink.com

Ettinger, A. B., Devinsky, O., Weisbrot, D. M., Goyal, A., \& Shashikumar, S. (1999). Headaches and other pain symptoms among patients with psychogenic non-epileptic seizures. Seizure, 8(7), 424-426.

Espírito Santo, J. L. do, Maineri, N., Portuguez, Z., \& Mirna, W. (2004). Epilepsia e Crises Não-Epilépticas Psicogênicas. Journal of Epilepsy and Clinical Neurophysiology, v. 10, 29-33.

Fiszman, A., Alves-Leon, S. V. A., Nunes, R. G., D’Andrea, I., \& Figueira, I. (2004). Traumatic events and posttraumatic stress disorder in patients with psychogenic nonepileptic seizure: a critical review. Epilepsy \& Behavior, 5, 818-825.

Freud, S. (1977). Algumas considerações para um estudo comparativo das paralisias motoras orgânicas e histéricas. In: Edição Standard Brasileira das Obras Psicológicas Completas de Sigmund Freud (J. Salomão, trad.) [CD-ROM]. Rio de Janeiro: Imago. (Trabalho original publicado em 1893).

(1977). As psiconeuroses dedefesa. In: Edição Standard Brasileira das Obras Psicológicas Completas de Sigmund Freud (J. Salomão, trad.) [CD-ROM]. Rio de Janeiro: Imago. (Trabalho original publicado em 1894). 
. (1976). Carta 69. Extratos dos documentos dirigidos a Fliess. In: Edição Standard Brasileira das Obras Psicológicas Completas de Sigmund Freud. Rio de Janeiro: Imago. (Trabalho original publicado em 1897).

(1977). A Interpretação de sonhos. In: Edição Standard Brasileira das Obras Psicológicas Completas de Sigmund Freud (J. Salomão, trad.) [CD-ROM]. Rio de Janeiro: Imago. (Trabalho original publicado em 1900).

. (1977). Sonhos da bela açougueira. In: Edição Standard Brasileira das Obras Psicológicas Completas de Sigmund Freud (J. Salomão, trad.) [CD-ROM]. Rio de Janeiro: Imago. (Trabalho original publicado em 1900).

(1977). Três ensaios sobre a sexualidade. In: Edição Standard Brasileira das Obras Psicológicas Completas de Sigmund Freud (J. Salomão, trad.) [CD-ROM]. Rio de Janeiro: Imago. (Trabalho original publicado em 1905).

. (1977). Sobre um tipo de escolha especial do homem. In: Edição Standard Brasileira das Obras Psicológicas Completas de Sigmund Freud (J. Salomão, trad.) [CDROM]. Rio de Janeiro: Imago. (Trabalho original publicado em 1910).

(1977). A dinâmica da transferência. In: Edição Standard Brasileira das Obras Psicológicas Completas de Sigmund Freud (J. Salomão, trad.) [CD-ROM]. Rio de Janeiro: Imago. (Trabalho original publicado em 1912).

. (1977). Totem e Tabu. In: Edição Standard Brasileira das Obras Psicológicas Completas de Sigmund Freud (J. Salomão, trad.) [CD-ROM]. Rio de Janeiro: Imago. (Trabalho original publicado em 1913).

(1977). A História do Movimento Psicanalítico. In: Edição Standard Brasileira das Obras Psicológicas Completas de Sigmund Freud (J. Salomão, trad.) [CD-ROM]. Rio de Janeiro: Imago. (Trabalho original publicado em 1914).

. (1977). Um caso de paranóia contrária à teoria psicanalítica. In: Edição Standard Brasileira das Obras Psicológicas Completas de Sigmund Freud (J. Salomão, trad.) [CDROM]. Rio de Janeiro: Imago. (Trabalho original publicado em 1915).

(1977). Uma criança é espancada. In: Edição Standard Brasileira das Obras Psicológicas Completas de Sigmund Freud (J. Salomão, trad.) [CD-ROM]. Rio de Janeiro: Imago. (Trabalho original publicado em 1919). 
. (1977). Dois Verbetes de enciclopédia. In: Edição Standard Brasileira das

Obras Psicológicas Completas de Sigmund Freud (J. Salomão, trad.) [CD-ROM]. Rio de Janeiro: Imago. (Trabalho original publicado em 1923).

(1977). A Dissolução do Complexo de Édipo. In: Edição Standard Brasileira das Obras Psicológicas Completas de Sigmund Freud (J. Salomão, trad.) [CD-ROM]. Rio de Janeiro: Imago. (Trabalho original publicado em 1924).

. (1977). Algumas consequências psíquicas da distinção anatômica entre os sexos. In: Edição Standard Brasileira das Obras Psicológicas Completas de Sigmund Freud (J. Salomão, trad.) [CD-ROM]. Rio de Janeiro: Imago. (Trabalho original publicado em 1925).

(1977). Inibição, sintoma e angústia. In: Edição Standard Brasileira das Obras Psicológicas Completas de Sigmund Freud (J. Salomão, trad.) [CD-ROM]. Rio de Janeiro: Imago. (Trabalho original publicado em 1926).

. (1977). A sexualidade feminina. In: Edição Standard Brasileira das Obras Psicológicas Completas de Sigmund Freud (J. Salomão, trad.) [CD-ROM]. Rio de Janeiro: Imago. (Trabalho original publicado em 1931).

Florindo, S., \& Pereira, M. E. C. (2003). Semiologia e características clínicas das crises pseudo-epilépticas. Rev. latinoam. psicopatol Fundam, 6(1),109-129.

Harden, C. (1997). Pseudoseizures and dissociative disorders: a commom mechanism involving traumatic experiences. Seizure, 6: 151-155

Jawad, S. S., Jamil, N., Clarke, E. J., Lewis, A., Whitecross, S., \& Richens, A. (1995). Psychiatric morbidity and psychodynamics of patients with convulsive pseudoseizures. Seizure, 4(3), 201-206.

Kupermann, D. (1996). Transferências cruzadas: uma história da psicanálise e suas instituições. Rio de Janeiro: Revan.

LaFrance W. C., Alper K., Babcock, D. J., Barry J.J., Bendadis S., Caplan, R et al. (2006). Nonepileptic seizures treatment workshop summary. Epilepsy \& Behavior, 8 (3), 451-61.

Mannoni, O. (1989). A psicanálise e a ciência. In: M. Augé et al. O objeto em psicanálise (pp. 149-166). Campinas, SP: Papirus. 
Marques, L. H. N., Almeida, S. J. A. de, \& Santos A. B. (2004). Monitorização vídeoEEG prolongada em crises não epilépticas. Arq Neuropsiquiatr, 62(2-B), 463-468.

Marquez, A. V., Farias, S. T., Apperson, M., Koopmans, S., Jorgensen, J., Shatzel, A. et al. (2004). Psychogenic nonepileptic seizures are associated with an increased risk of obesity. Epilepsy \& Behavior, 5(1), 88-93.

Miguelez, M. B. S. (2007). Complexo de Édipo, novas patologias, novas mulheres, novos homens. São Paulo: Casa do Psicólogo, 2007.

Nasio, J. D. (1991). A histeria: teoria e clínica psicanalítica. Rio de Janeiro: Jorge Zahar Editor.

Palonsky, C. (1997). Estruturas clínicas na clínica: a histeria. Belo Horizonte: PUC Minas.

Parra, J., Iriarte, J., \& Kanner, A. M. (1999). Are we overusing the diagnosis of psychogenic non-epileptic events? Seizure, 8(4), 223-227.

Prigatano, G. P., Stonnington, C., \& Fisher R. S. (2002). Psychological factors in the genesis and management of nonepileptic seizures: clinical observations. Epilepsy \& Behavior, 3, 343-349.

Roudinesco, E., \& Plon, M. (1998). Dicionário de psicanálise. Rio de Janeiro: Jorge Zahar Editor.

Rowan, A. J. (2000). Diagnosis of non-epileptic seizures. In: J. R. Gates, \& A. J. Rowan, A. J. (Eds.), Non-epileptic seizures (2a ed. pp. 15-30). Boston: Butterworth-Heinemann.

Sander, W. J., \& Hart, Y. M. (1999). Epilepsia: um guia prático. São Paulo: Merit.

Sluhovsky, M. (2002). The devil in the convent. American Historical Review, 107, 13791411.

Taoufik, M., Alsaadi, M. D., \& Marquez, A. V. (2005). Psychogenic Nonepileptic Seizures. American Family Physician, 72(5) 849-56. 
Trillat, E. (1991). História da histeria. São Paulo: Escuta.

Turato, E. R. (2003). Tratado da Metodologia da Pesquisa Clínico-Qualitativa: construção teórico-epistemológica, discussão comparada e aplicação nas áreas da saúde e humanas. 2. ed. Petrópolis: Vozes.

Vanderzant, C. W., Giordani, B., Berent, S., Dreifuss, F. E., \& Sackellares, J. C. (1986). Personality of patients with pseudoseizures. Neurology, 36, 664-668.

Waller, J. (2008). A time to dance, a time to die: the extraordinary story of the dancing plague of 1518. Cambridge: Icon Books.

Wilkus, R. J., Dodrill, C. B., \& Thompson, P. M. (1984). Intensive EEG monitoring and psychological studies of patients with pseudoepileptic seizures. Epilepsia, 25,100-107.

Wolanczyk, T., \& Brynska, A. (1998). Psychogenic seizures in obsessive-compulsive disorder with poor insight: a case report. Pediatric Neurology, 18(1), 85-86. 
ANeXo 


\section{TERMO DE CONSENTIMENTO LIVRE E ESCLARECIDO}

Você está sendo convidado a participar de uma pesquisa cujo objetivo é verificar de que maneira a psicoterapia de orientação psicanalítica pode contribuir para a compreensão e o tratamento de pessoas que têm problemas parecidos com os que você vem enfrentando. Caso aceite participar, serão utilizadas as informações que foram fornecidas nos atendimentos clínicos que você realizou na clínica psicológica da USP, assim como as informações que virá a fornecer até o término desta pesquisa. Caso aceite participar, esses dados ajudarão na compreensão de seus problemas e poderão trazer benefícios para outras pessoas em situações semelhantes a que você enfrenta ou enfrentou.

Você poderá ter acesso às informações sobre procedimentos, riscos e benefícios relacionados à pesquisa, inclusive para esclarecer eventuais dúvidas. A qualquer tempo você também poderá retirar seu consentimento da pesquisa e deixar de participar do estudo, sem que isto traga prejuízo aos atendimentos que você já realiza na clínica.

Serão garantidos a privacidade e o sigilo das informações os e dados que poderiam ajudar na sua identificação serão omitidos do trabalho final assegurando seu caráter confidencial. Os resultados da pesquisa poderão ser publicados, porém, você não será identificado e sua privacidade e sigilo estarão garantidos.

Declaro que, após convenientemente esclarecido pelo pesquisador e ter entendido o que me foi explicado, consinto em participar do presente Protocolo de Pesquisa.

São Paulo, de de 200 .

assinatura do sujeito da pesquisa ou responsável legal

assinatura do pesquisador

(carimbo ou nome Legível)

\section{DADOS DO PESQUISADOR RESPONSÁVEL:}

Elaine Cristina Guater

INSCRIÇÃO CONSELHO REGIONAL Nº: 06/73985

ENDEREÇO: Av. Prof. Mello Moraes, 1721 - CEP 05508-030 - Cidade Universitária - São Paulo

TELEFONE: (11) 3091-4173/ (11) 3091-4910

\section{COMITÊ DE ÉTICA E PESQUISA COM SERES HUMANOS DO IPUSP}

ENDEREÇO: Av Prof. Mello Moraes, 1721, Bloco G, sala 22, Cidade Universitária - São Paulo, SP fone: (11) 3097-0529. 